\title{
Incised stone artefact in the context of Middle Holocene burials at Cappalombo 1, South Sulawesi, Indonesia Artefak batu bergores dalam konteks penguburan Holosen Tengah di Situs Cappalombo 1, Sulawesi Selatan, Indonesia
}

\author{
Suryatman ${ }^{1,2}$ *, Fakhri ${ }^{1,2}$, Budianto Hakim², \\ Yinika L. Perston ${ }^{3}$, Ratno Sardi ${ }^{2}$, Kim \\ Newman ${ }^{3}$, Hasanuddinn, ${ }^{2,4}$, Muhammad Nur ${ }^{4}$, \\ Khadijah Tahir Muda ${ }^{4}$ \\ ${ }^{1}$ Graduate Students of Archaeology \\ Department, Faculty of Cultural Science, \\ Hasanuddin University, Makassar, Indonesia \\ ${ }^{2}$ Balai Arkeologi Provinsi Sulawesi Selatan, \\ Makassar, Indonesia \\ ${ }^{3}$ Australian Research Centre for Human \\ Evolution at Griffith University, School of \\ Environment and Sciences, Brisbane, Qld, \\ Australia \\ ${ }^{4}$ Archaeology Department, Faculty of \\ Cultural Science, Hasanuddin University, \\ Makassar, Indonesia \\ *Correspondence: \\ suryatman01@kemdikbud.go.id
}

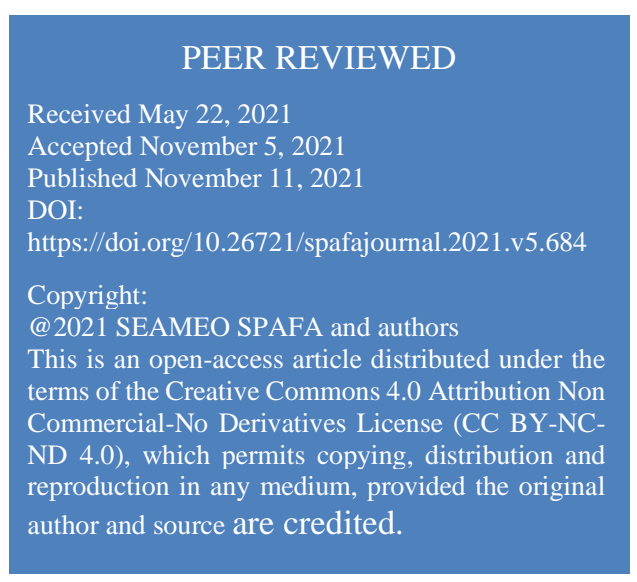

PEER REVIEWED

Received May 22, 2021

Accepted November 5, 2021

Published November 11, 2021

DOI:

@2021 SEAMFO SPAFA and authors

This is an open-access article distributed under the the Creative Commons 4.0 Attribution Non (CC BY-NCuthor and source are credited.

\begin{abstract}
Since the recent discovery of Late Pleistocene rock art in Island Southeast Asia was announced, evidence for symbolic behaviour in the region has become a focus of international archaeological interest. South Sulawesi is one region that hold much evidence for this important human activity. In addition to the cave paintings, several engraved stone artefacts have also been recovered in the same area, nearly all of which date back to the Late Pleistocene. However, while cave use by 'hunter-gatherer' societies continued into the Holocene period, archaeological evidence for symbolic expression during this Toalean period is extremely rare. Here, we report for the first time on engraved stone artefacts from the Middle Holocene period, associated with six human burials. Of ten incised artefacts recovered, eight are stone flakes and two are stone plaquettes, all made of hematite material. Our study suggests that unlike comparative Pleistocene engraved stones, the incisions on the Cappalombo artefacts are more likely the result of use-wear that occurs from producing red pigment powder than portable artworks. As no Toalean-age cave art has yet been identified, it is suspected that pigment powder was applied to the corpses as part of a burial practice or perhaps smeared on the body of the person/s performing the ceremony itself as part of a symbolic ritualistic activity.
\end{abstract}

Sejak penemuan gambar cadas Pleistosen Akhir terbaru diumumkan di Pulau Asia Tenggara, bukti perilaku simbolis di wilayah tersebut telah menjadi fokus kajian arkeologis internasional. Sulawesi Selatan adalah salah satu wilayah yang menyimpan banyak bukti aktivitas manusia yang penting ini. Selain lukisan gua, beberapa artefak batu berukir juga telah ditemukan di daerah yang sama, 
hampir semuanya berasal dari Pleistosen Akhir. Namun, ketika penggunaan gua oleh masyarakat 'pemburu-pengumpul' berlanjut hingga periode Holosen, bukti arkeologis untuk ekspresi simbolis selama periode Toalean ini sangat langka. Di sini, kami melaporkan untuk pertama kalinya tentang artefak batu berukir dari periode Holosen Tengah, yang terkait dengan enam penguburan manusia. Dari sepuluh artefak gores yang ditemukan, delapan berupa serpihan batu dan dua berupa plakat batu, semuanya terbuat dari bahan hematit. Studi kami menunjukkan bahwa tidak seperti batu terukir Pleistosen, sayatan pada artefak Cappalombo lebih mungkin hasil dari penggunaan yang terjadi dari memproduksi bubuk pigmen merah daripada karya seni portabel. Karena seni gua periode Toalean belum dapat diidentifikasi, diduga bubuk pigmen dioleskan pada mayat sebagai bagian dari praktik penguburan atau mungkin dioleskan pada tubuh orang yang melakukan upacara itu sendiri sebagai bagian dari aktifitas ritual simbolis.

Keywords: Engraved artefacts, symbolic behaviour, hematite, pigment powder, burial, South Sulawesi | Artefak berukir, perilaku simbolik, hematit, bubuk pewarna, penguburan, Sulawesi Selatan

\section{Introduction}

Incised marks on artefacts at Late Pleistocene sites are often interpreted as symbolic behaviour and evidence for the cognitive state of modern humans (d'Errico and Henshilwood 2011; Malafouris 2021). It is even thought that such scratches, engravings or marks may form part of communication systems or social interactions, both within social groups and as records for future generations (Henshilwood and d'Errico 2011; Langley et al. 2020; Ruiz-Redondo et al. 2020). There are increasing reports of scratched artefacts being documented throughout the "Old World" regions and the existence of such artefacts have become a topic of global debate (Henshilwood et al. 2002, 2009, 2018; Yaroshevich et al. 2016; Dutkiewicz et al. 2020). Such markings, often found in association with other complex artefacts such as microliths and jewellery, demonstrates that symbolic behaviour was a part of the behavioural package of early modern humans that left Africa after the Toba eruption, although this topic remains heavily debated (see Petraglia et al. 2009; Hiscock et al. 2011; Mellars et al. 2013; Clarkson et al. 2018).

In recent years, symbolic markings have come to prominence in Southeast Asia with the discovery of late Pleistocene rock images announced in 2014, which has since been followed by a number of similar discoveries (Aubert et al. 2014, 2018, 2019; Brumm et al. 2021). These and other finds demonstrated that the artistic and cognitive capabilities of the inhabitants of this isolated tropical environment were comparable to their contemporaries in Europe, including an ability to produce carved artworks. For example, incised stone artefacts with geometric patterns have been reported from the Xom Trai Cave Site, dating to 22-19 thousand years ago (kya) (Nguyen 2015). In a second example, unique engravings of humanoid faces and figures have been reported on carbonate flows at three rockshelter sites in East Timor, one of which has been dated using the Uranium-Thorium method to 12.5-10.2 kya (O’Connor et al. 2010, 2020).

Intensive research has shown that Sulawesi, one of the largest islands in central Island Southeast Asia (ISEA), holds much evidence for the cognitive abilities of early modern humans in the region. In particular, recent studies have found multiple examples of symbolic markings scattered throughout the limestone karst region that stretches through much of the South Sulawesi province (Aubert et al. 2019; Brumm et al. 2021). In addition to cave paintings, a number of incised stone 
artefacts have also been recovered from stratigraphic deposits associated with the Late Pleistocene occupation phase. Incised marks on two stone plaquettes, described as portable art, have been associated with dates of 14-26 kya at the cave site of Leang Bulu Bettue (Brumm et al. 2017; Langley et al. 2020). Several additional pieces from the same site have been classified as engraved artefacts, as these are knapped stone flakes with engraved lines within the cortex that was preserved on the dorsal face (Brumm et al. 2017, 2020). In addition to these, stretches of short parallel lines engraved into a vertical limestone rock face have been reported at a nearby rockshelter in the same region, though a direct association between the sites has not been demonstrated (Brumm et al. 2020; Perston et al. 2020).

Within Sulawesi, dated examples of incised artefacts appear to exclusively belong to the Pleistocene, roughly contemporaneous with the cave paintings. Because of this, these marks are seen to represent symbolic behaviours that may have developed during this period (Brumm et al. 2017, 2020). However, hunter-gatherer groups continued to utilize the same cave spaces into the Holocene period. Indeed, cave spaces continued to be utilized after the introduction of agriculture by Austronesian-speaking migrants (Bellwood 2007) and even today are often used as natural barn spaces (pers. obs.). However, while there are rich faunal and lithic assemblages from this Holocene hunter-gatherer period, known as the Toalean period, very little evidence has previously been recovered to suggest that the production of such symbolic markings was continued. This is despite the regional development of complex artefact types, likely associated with the development of composite hunting equipment (Bulbeck et al. 2001; Suryatman et al. 2019, 2020; Hasanuddin et al. 2020; Perston et al. 2021). Here we report for the first time on the discovery of 'engraved' stone artefacts from Toalean deposits, at the rockshelter site of Cappalombo 1 . These artefacts are associated with human burials and abundant hematite nodules. This article will attempt to address the following questions: What was the purpose of incising these Toalean artefacts? And is this comparable to the activities of the Pleistocene predecessors who first introduced the practice of symbolic modification to the region?

\section{Archaeological context and dating}

Cappalombo 1 is a rockshelter located in the Bontocani district of the Bone regency of South Sulawesi. The rockshelter lies within the geological feature known as the Tonasa limestone karst formation, a highland region that is distinct from that containing a cluster of archaeological sites in the Maros-Pangkep karsts of lowland South Sulawesi (Figure 1). The site falls under the administration of Pattuku village. The coordinates for Cappalombo 1 are $5^{\circ} 04^{\prime} 29.26^{\prime \prime} \mathrm{S}$ by $119^{\circ} 57^{\prime} 46.5^{\prime \prime}$ E, with an altitude 628 meters (m) above sea level. The chamber of the rockshelter itself is $8 \mathrm{~m}$ deep, 6-8 $\mathrm{m}$ tall, and has a width of 12-15 $\mathrm{m}$ (Figure 2). 


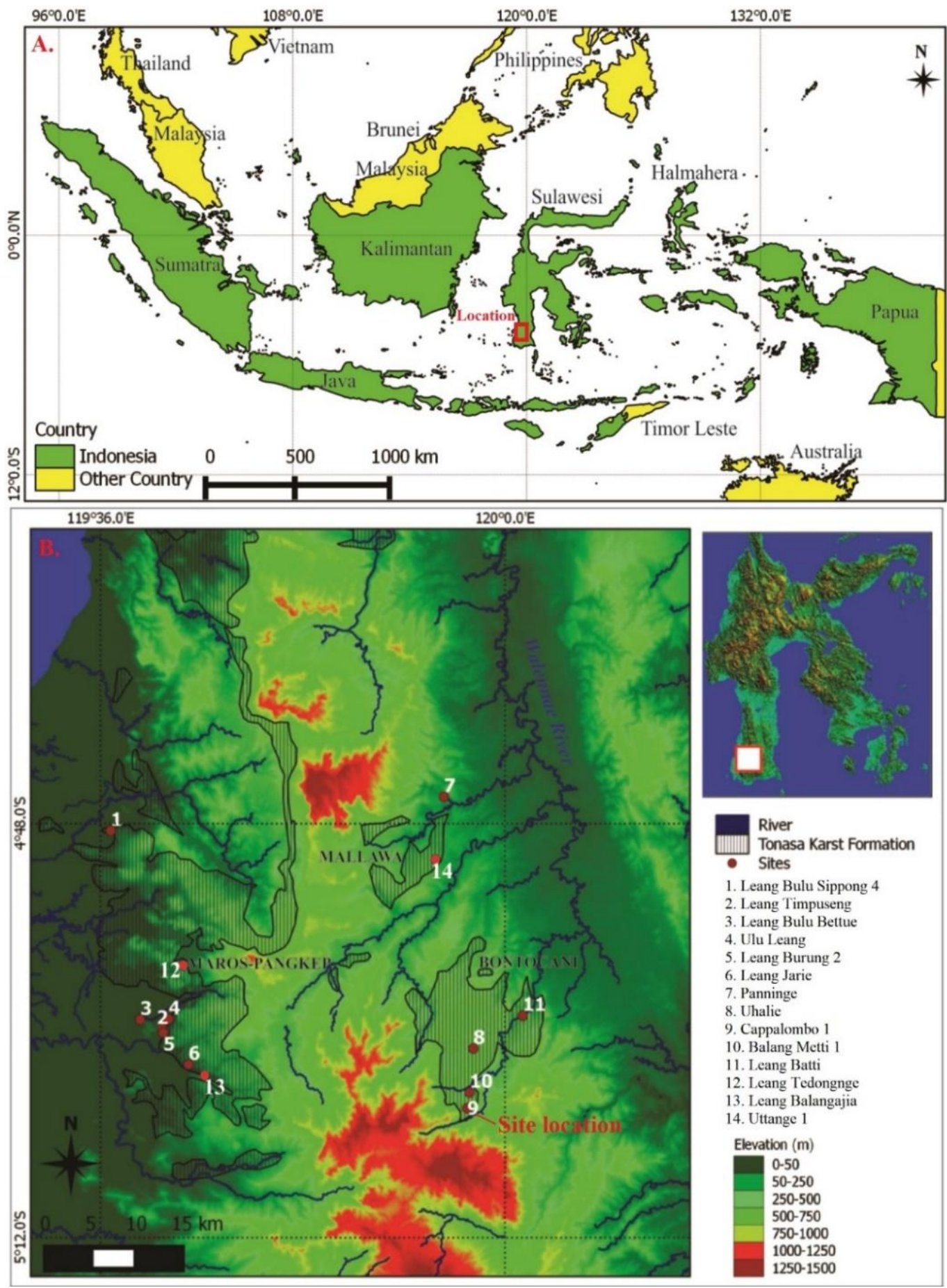

Fig. 1 Study location. Map showing the location of research (red box) within South Sulawesi, Indonesia (A). Archaeological sites are distributed through the Tonasa karst formation, and the site of Cappalombo 1 is situated in the Bontocani district, in the highlands of South Sulawesi (B). Map data: Geologic map of the Pangkajene and Western part of Watampone Quadrales and map of the Ujung Pandang, Bantaeng and Sinjai Quadrales, Sulawesi, 1:250.000, by Sukamto, 1982; Shuttle Radar Topography Mission, 2014. 


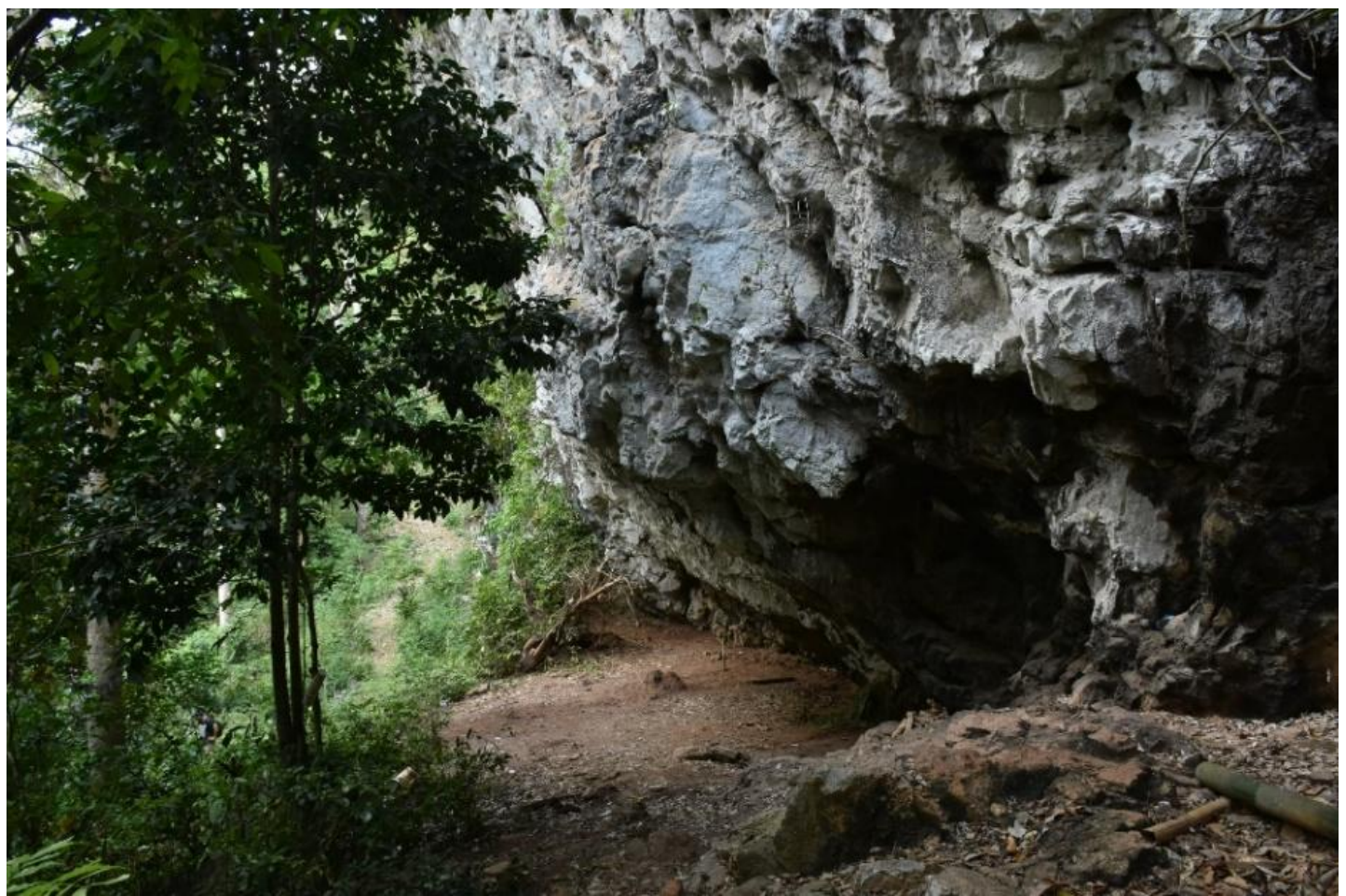

Fig. 2 Overview of Cappalombo 1 rockshelter. Photo: Fakhri et al., 2018.

The Cappalombo 1 site was first reported in 2014 when a team from Balai Arkeologi Sulawesi Selatan (Regional Agency for Archaeological Research in South Sulawesi Province), surveyed the Bontocani district (Fakhri 2017; Fakhri et al. 2018). Archaeological excavations were conducted in 2017 and 2018. Excavations in 2017 were conducted to open test pit (TP) 1 and TP2, both measuring 1 square meter, and TP3 measuring $1 \mathrm{~m}$ by $0.5 \mathrm{~m}$ (Fakhri 2017; Figure 3 and 4A). Excavations were carried out in $10 \mathrm{~cm}$ spits. The test pits reached depths of 70 to $90 \mathrm{~cm}$ and ceased when bedrock was encountered. Finds recovered from the excavations included red hematite nodules, hereafter referred to as 'ochre' a term which may apply to any natural earth mineral product that could culturally be utilised as a pigment (Huntley 2021). These ochre nodules have a combined weight of $7.4 \mathrm{~kg}$ (Figure 5), and additional finds included stone artefacts weighing $48 \mathrm{~kg}$ in total, 767 grams of shells, and $18.6 \mathrm{~kg}$ of bone fragments. Pottery fragments were also recovered, totalling 69 pieces, however these only occurred up to a depth of $60 \mathrm{~cm}$ below the datum (BD), i.e., spits 1 to 4 (Table 1). The datum and baseline were strung $10 \mathrm{~cm}$ above the highest point of the excavation wall, i.e., the datum sits $10 \mathrm{~cm}$ above ground level. As an assessment of the bone points from the 2017 excavation is ongoing, the total number of these artefacts recovered in the initial excavation is not yet known. Note that while these are most commonly referred to as bone points, the term 'osseous point' is perhaps more correct as some were also made from animal teeth (e.g., Fakhri 2018; Perston et al. 2021).

The remains of three individuals were recovered from the first excavation, these being CPL1 which was recovered from square TP1, and CPL2 and CPL3 from square TP2. CPL1 and CPL3 were found in a state of degradation and were incomplete, but the small size of the bones indicates that both skeletons were those of infants (Figure 3 and 4A). Identifiable elements include phalange and metapodial concentrations. Those remains of the CPL2 individual that could be recognized comprise part of the skull, though in a fragile condition. The rest of the skeletal elements have been lost or damaged. 
Excavations were extended in 2018, by opening and excavating along a north-south grid (Fakhri et al. 2018). The new excavation squares were placed above the previous squares (TP1-TP3) with the aim of reopening and expanding the previous excavation. The 2018 squares were designated S1T1, S1T2, U1T1 and T1T2 (Figure 4A). Excavations reached up to $90 \mathrm{~cm} \mathrm{BD}$, and most of the squares reached bedrock. The datum and baseline were strung $10 \mathrm{~cm}$ above the highest point of the excavation wall. The finds recovered from the four 2018 excavation squares consisted of ochre (4.359 kg in total), stone artefacts $(46.6 \mathrm{~kg})$, bone fragments $(11.7 \mathrm{~kg})$, and 553 grams of shells (Table 1). Pottery fragments totalled 54 pieces and only occurred in spits 1-4 to a depth of up to 60 cm BD. Bone points were also identified during the 2018 excavation, totalling 74 pieces (Table 1 and Figure 6U).

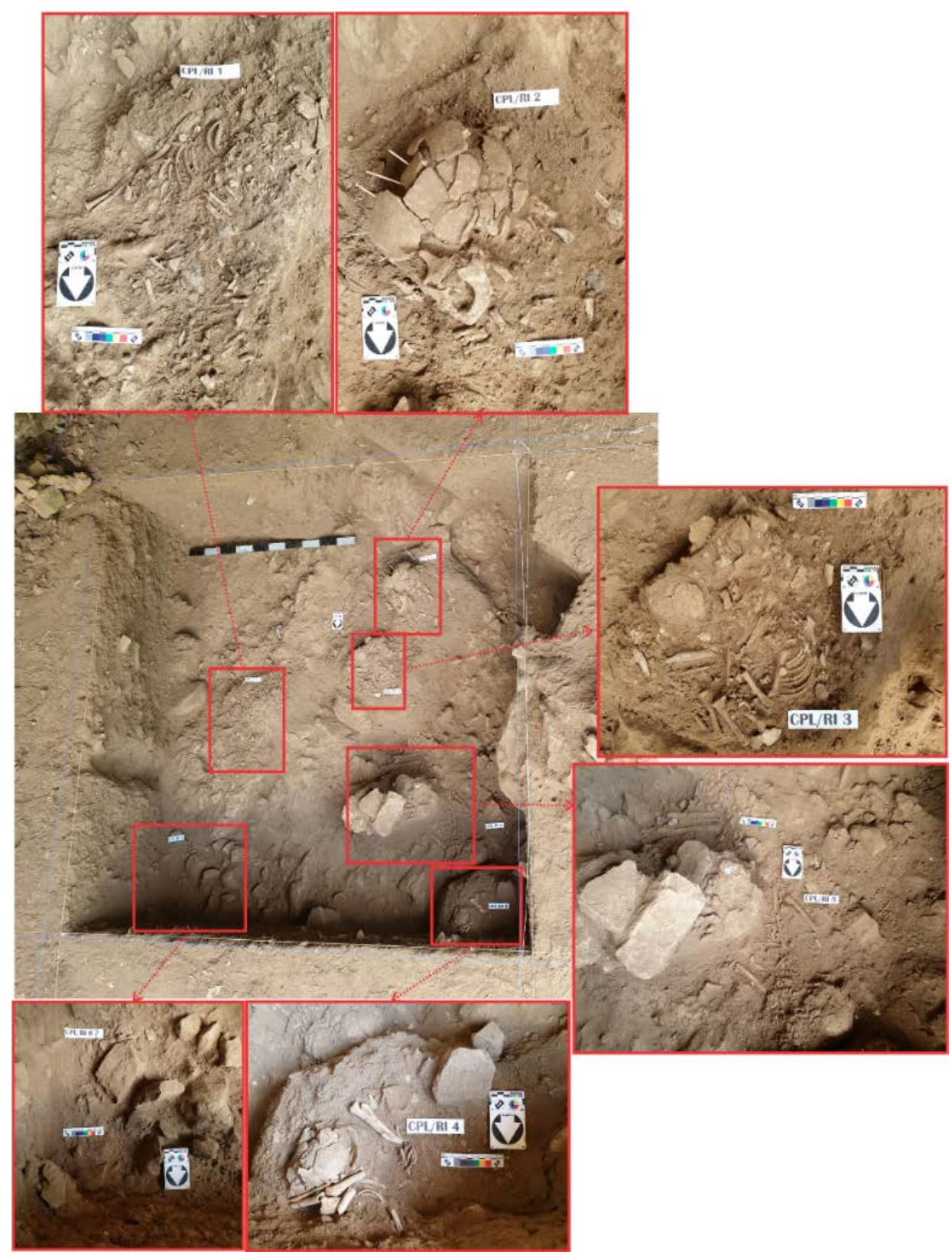

Fig. 3 Six human skeletons recovered from excavation squares in 2017 and 2018 at the Cappalombo 1 site. Source: Fakhri et al. 2018. 


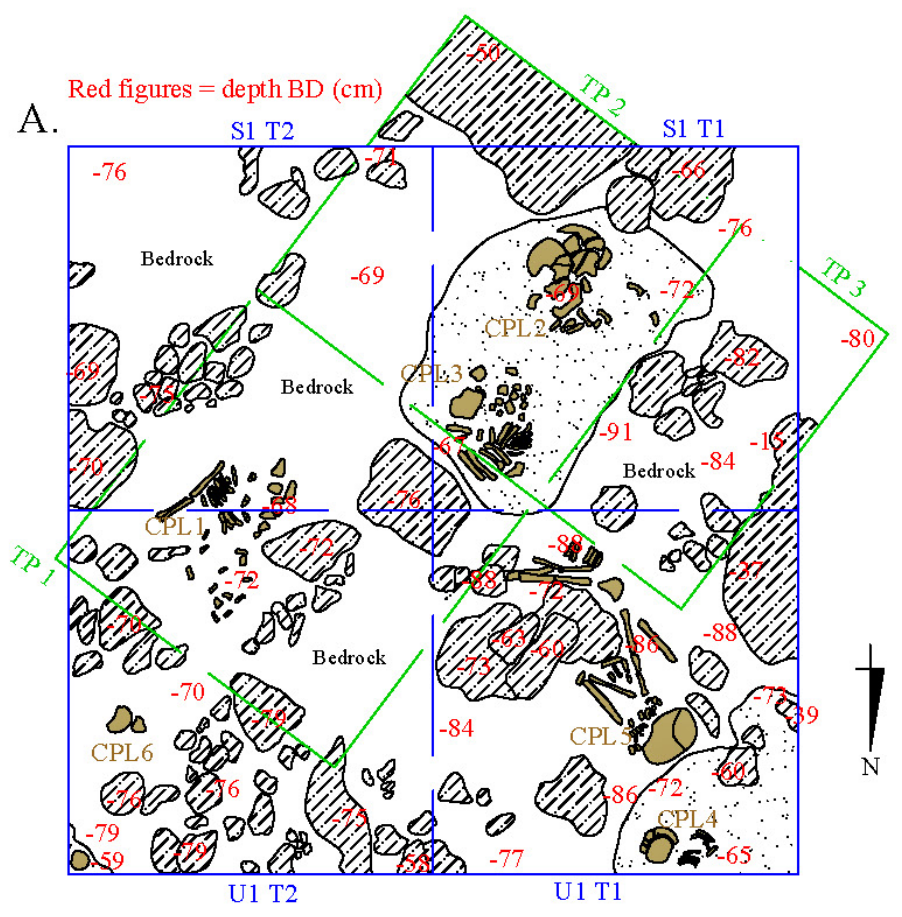

B.

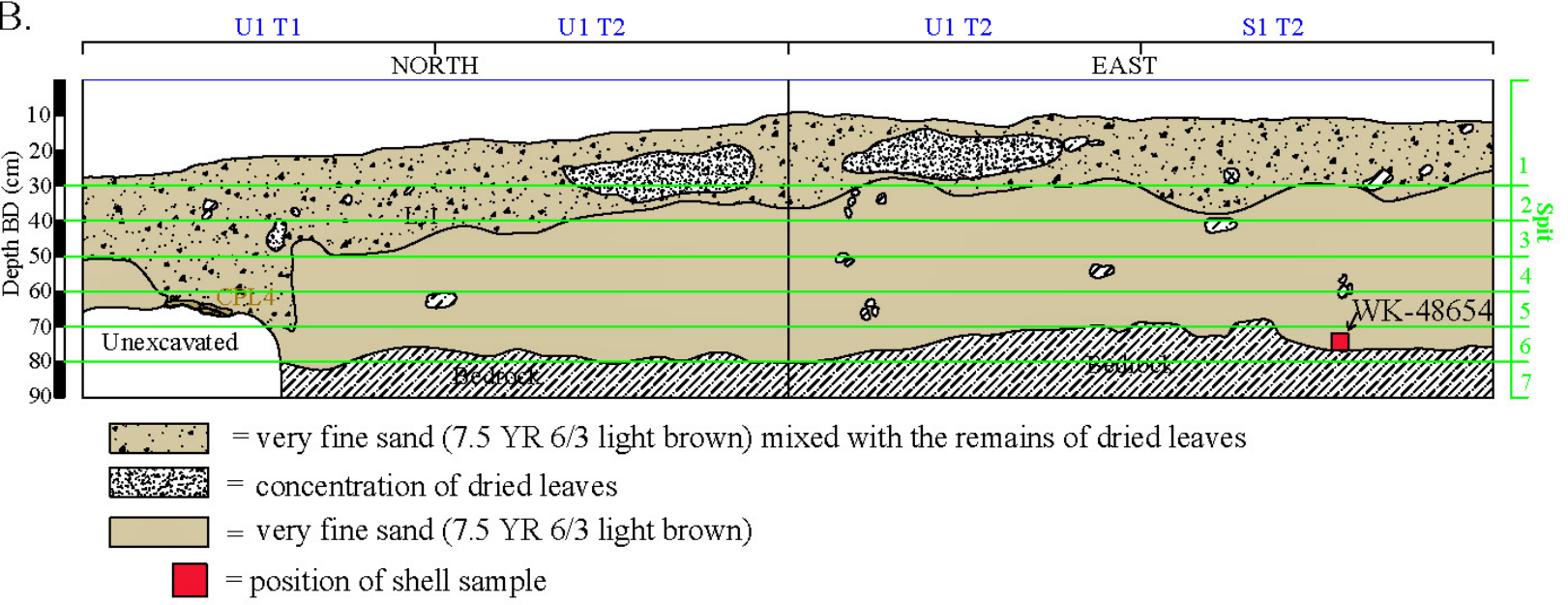

Fig. 4 Cappalombo 1 trench plans showing the 2017 excavations (green) (TP1, TP2 and TP3) and the 2018 excavations (blue) (U1T1, S1T2, S1T1 and S1T2), as well as the position of the remains of six human skeletons relative to the excavation squares (A). Stratigraphic section of the excavation at the Cappalombo 1 site, showing the north and east walls at the end of the 2018 excavation. The shell sample (Wk-48654) was recovered from square S1T2, spit 6, at $80 \mathrm{~cm}$ deep and close to the skeletal remains CPL1 (B).

During the 2018 excavation, the skeletal remains of a further three individuals were identified. These were designated CPL4 and CPL5, located in square U1T1, and CPL6 in square U1T2 (Figures 3 and 4A). Individuals CPL4 and CPL7 comprise only of cranial fragments, while the CPL5 individual was more complete and elements including the right occipital and right temporal bones, the mandible, a number of phalanges, left and right humerus, pelvis, and both femurs were recovered. The CPL5 skeleton also showed signs of being buried in a flexed position. The abdomen and shoulders of CPL5 were confined by boulders (Figures 3 and 4A). The skeletal elements are currently the subject of ongoing analysis. 
Only one stratigraphic layer of soil could be identified in the excavations, a layer of very fine, loose sand. This layer was light brown (7.5/YR 6/3). This can be split into two layers based on the inclusion of modern organics. The upper $20-40 \mathrm{~cm}$ appears to be mixed with the topsoil and humus, as dried leaves were encountered (Figure 4B). This upper, leaf-bearing layer is thought to have been disturbed by modern human activity at the site. In contrast, the layer containing human remains, is 30-50 cm thick and does not appear to be disturbed as no leaves or modern items were encountered. Pottery fragments were also not recovered from the lower layer. Bedrock was encountered at a depth of 70-90 $\mathrm{cm}$ from the baseline, i.e., $60-80 \mathrm{~cm}$ from the highest point of the walls of the excavation. All human skeletal remains were located close to the bedrock.

Charcoal samples were not recovered from the lower deposits, and so alternative samples were used for dating. Samples collected for radiocarbon dating consisted of the right femur of individual CPL5 (WK-48625) and a fragment of a mangrove Bivalvia species (WK-48654), both from square S1T2 spit 6, at a depth of 70-80 cm. The shell sample was recovered close to the CPL1 skeleton. Both samples were analysed by the University of Waikato radiocarbon dating laboratory. Attempts to date the femur sample were unsuccessful as there was insufficient collagen preservation (pers. comm. Fiona Petchey, December 5, 2018). However, the Bivalvia sample was successfully dated, and calibrated using OxCal v4.4.4 (Bronk Ramsey 2021) and the Marine20 curve (Heaton et al. 2020). The results show that the Bivalvia sample dates to 6396-6305 cal BP (95.4\%) (5569 $\pm 20 \mathrm{BP}$ (WK-48654)) (Figure 4B), and by extension CPL1 is likely of a similar antiquity.

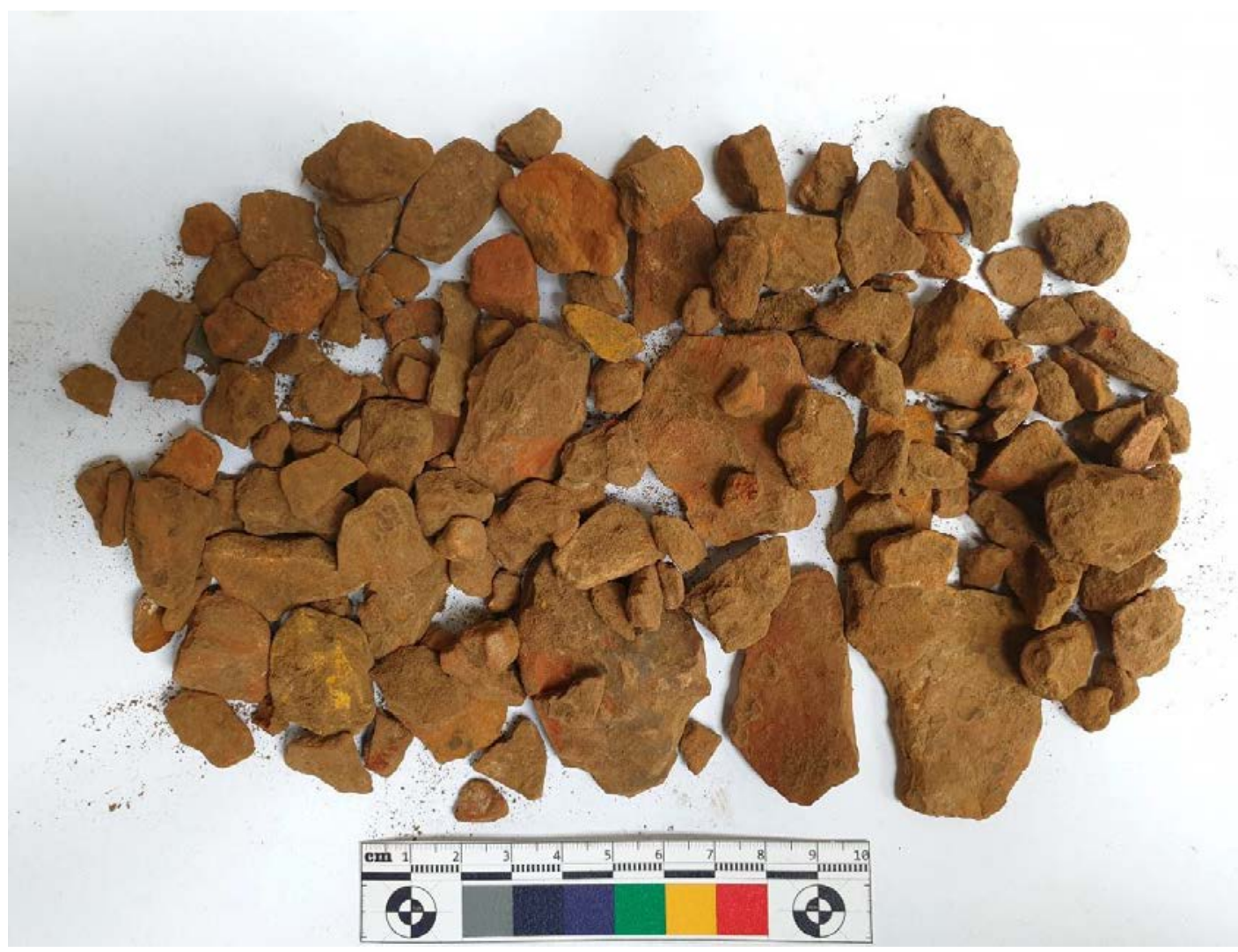

Fig. 5 Sample of ochre nodules recovered from excavation square U1T2, spit 6, during the 2018 excavation.

The stone artefacts recovered from squares TP1 and TP2 (excavated in 2017) and U1T2 (excavated in 2018) were analysed for the present study. This sample was selected as time limits did not permit 
a full analysis and artefacts appeared to be fairly evenly distributed across the excavations (Table 2). The analysed artefact assemblage is dominated by debitage ( $n=20,377,96 \%)$, here defined as flakes and other knapping by-products with no observable evidence for use or secondary modification. The remaining $4 \%$ comprises of flake tools and cores $(n=821)$. Flake tools consisted of unmodified flakes with macroscopic signs of use as well as several retouched forms, namely Maros points $(n=224)$, retouched scrapers $(n=49)$, and microliths. The term microlith refers to any small stone blank with backing along at least part of one margin. The backed microliths have been subdivided into two subtypes, namely asymmetric microliths $(n=46)$ and geometric microliths $(n=48)$ (Figure 6). Retouched flake tools that were too damaged to classify totalled 119 pieces. Maros points were most numerous in spits 4-6, and less frequent in spits 1-3. In contrast, microliths were most numerous in spits 1-3. Geometric microliths were only recovered from spits 13 (Table 2).

\begin{tabular}{|l|l|c|c|c|c|c|c|}
\hline \multirow{2}{*}{$\begin{array}{l}\text { Excav. } \\
\text { Year }\end{array}$} & $\begin{array}{l}\text { Spit/ } \\
\text { Depth } \\
(\mathrm{cm})\end{array}$ & $\begin{array}{l}\text { Flaked } \\
\text { artefacts } \\
\text { (grams) }\end{array}$ & $\begin{array}{l}\text { Bone } \\
\text { (grams) }\end{array}$ & $\begin{array}{l}\text { Ochre } \\
\text { (grams) }\end{array}$ & $\begin{array}{l}\text { Shell } \\
\text { (grams) }\end{array}$ & $\begin{array}{l}\text { Pottery } \\
\text { (count) }\end{array}$ & $\begin{array}{l}\text { Bone } \\
\text { point } \\
\text { (count) }\end{array}$ \\
\hline \multirow{4}{*}{2018} & $1 / 10-30$ & 5262 & 795 & 154.87 & 31.30 & 31 & 3 \\
\cline { 2 - 8 } & $2 / 30-40$ & 11,274 & 2386 & 316.85 & 99.85 & 21 & 2 \\
\cline { 2 - 8 } & $3 / 40-50$ & 8075 & 2280 & 332.26 & 161.80 & 1 & 6 \\
\cline { 2 - 8 } & $4 / 50-60$ & 6312 & 1914 & 571.74 & 90.32 & 1 & 16 \\
\cline { 2 - 8 } & $5 / 60-70$ & 6705 & 2270 & 872.00 & 51.25 & 0 & 11 \\
\cline { 2 - 8 } & $6 / 70-80$ & 7668 & 1751 & 1848.20 & 106.67 & 0 & 8 \\
\cline { 2 - 8 } & $7 / 80-90$ & 1317 & 315 & 263.66 & 12.00 & 0 & 1 \\
\cline { 2 - 8 } & Total & 46,613 & 11,711 & 4359.58 & 553.19 & 54 & 47 \\
\hline 2017 & $1 / 10-30$ & 12,969 & 2874 & 629.00 & 135.00 & 44 & - \\
\cline { 2 - 8 } & $2 / 30-40$ & 10,589 & 3632 & 952.00 & 175.00 & 21 & - \\
\cline { 2 - 8 } & $3 / 40-50$ & 6859 & 3962 & 1152.00 & 163.00 & 1 & - \\
\cline { 2 - 8 } & $4 / 50-60$ & 7783 & 4618 & 2524.00 & 172.00 & 3 & - \\
\cline { 2 - 8 } & $5 / 60-70$ & 6204 & 2602 & 1664.00 & 71.00 & 0 & - \\
\cline { 2 - 8 } & $6 / 70-80$ & 2806 & 659 & 419.00 & 40.00 & 0 & - \\
\cline { 2 - 8 } & $7 / 80-90$ & 809 & 323 & 63.00 & 11.00 & 0 & - \\
\cline { 2 - 8 } & Total & 48,019 & 18,670 & 7403.00 & 767.00 & 69 & - \\
\hline
\end{tabular}

Table 1 Finds from Cappalombo 1 recovered from the 2017 excavation (TP1, TP 2 and TP 3) and the 2018 excavation (U1T1, U1T2, S1T2 and S1T2). Analysis of bone points recovered in 2017 is ongoing, and as a result the total count is not yet known. 


\begin{tabular}{|c|c|c|c|c|c|c|c|c|}
\hline \multirow{4}{*}{ Spit } & \multicolumn{8}{|c|}{ Flaked artefacts Category } \\
\hline & \multicolumn{6}{|c|}{ Flake Tools Type } & \multirow{3}{*}{ Debitage } & \multirow[b]{3}{*}{ Core } \\
\hline & \multicolumn{5}{|c|}{ Retouched } & \multirow[b]{2}{*}{$\begin{array}{l}\text { Utilised } \\
\text { flake }\end{array}$} & & \\
\hline & $\begin{array}{c}\text { Maros } \\
\text { Point }\end{array}$ & $\begin{array}{c}\text { Asymme } \\
\text { trical } \\
\text { microlith }\end{array}$ & $\begin{array}{l}\text { Geometri } \\
\text { c } \\
\text { microlith }\end{array}$ & $\begin{array}{l}\text { Retouched } \\
\text { scraper }\end{array}$ & Unidentified & & & \\
\hline 1 & 3 & 5 & 8 & 5 & 6 & 24 & 2031 & 20 \\
\hline 2 & 15 & 11 & 26 & 4 & 30 & 32 & 3302 & 32 \\
\hline 3 & 11 & 16 & 14 & 3 & 17 & 39 & 3458 & 27 \\
\hline 4 & 37 & 5 & 0 & 14 & 8 & 26 & 3527 & 17 \\
\hline 5 & 93 & 0 & 0 & 13 & 33 & 32 & 5036 & 33 \\
\hline 6 & 62 & 7 & 0 & 7 & 17 & 24 & 2184 & 17 \\
\hline 7 & 3 & 2 & 0 & 3 & 8 & 11 & 839 & 1 \\
\hline Total & 224 & 46 & 48 & 49 & 119 & 188 & 20,377 & 147 \\
\hline$\%$ & 1.06 & 0.22 & 0.23 & 0.23 & 0.56 & 0.89 & 96.13 & 0.69 \\
\hline
\end{tabular}

Table 2 Flake types recovered from the Cappalombo 1 excavations in 2017 (TP1 and TP 2) and 2018 (U1T2).

\begin{tabular}{|c|c|c|c|c|c|c|c|c|}
\hline \multirow{3}{*}{ Spit } & \multicolumn{8}{|c|}{ Material } \\
\hline & \multicolumn{2}{|c|}{ Chert } & \multicolumn{2}{|c|}{ Hematite } & \multicolumn{2}{|c|}{ Limestone } & \multicolumn{2}{|c|}{ Volcanic } \\
\hline & count & $\%$ & count & $\%$ & count & $\%$ & count & $\%$ \\
\hline 1 & 1984 & 10.54 & 29 & 2.44 & 15 & 24.19 & 41 & 6.34 \\
\hline 2 & 3174 & 16.87 & 111 & 9.33 & 13 & 20.97 & 66 & 10.20 \\
\hline 3 & 3292 & 17.49 & 135 & 11.34 & 6 & 9.68 & 76 & 11.75 \\
\hline 4 & 3187 & 16.94 & 233 & 19.58 & 5 & 8.06 & 154 & 23.80 \\
\hline 5 & 4594 & 24.41 & 374 & 31.43 & 12 & 19.35 & 139 & 21.48 \\
\hline 6 & 1826 & 9.70 & 265 & 22.27 & 10 & 16.13 & 137 & 21.17 \\
\hline 7 & 762 & 4.05 & 43 & 3.61 & 1 & 1.61 & 34 & 5.26 \\
\hline Total & 18,819 & 100 & 1190 & 100 & 62 & 100 & 647 & 100 \\
\hline
\end{tabular}

Table 3 Raw materials of stone artefacts recovered from Cappalombo 1during the excavations in 2017 (TP1 and TP2) and 2018 (U1T2).

The material used for flake production is dominated by chert, at $90.8 \%(n=18,819)$, while other materials include $5.7 \%$ hematite $(n=1190), 0.3 \%$ limestone $(n=62)$ and 3.1\% volcanic $(n=647)$. The high frequency of hematite flakes at the site is unusual as, to our knowledge, it is rare to recover flaked hematite from Toalean sites, let alone in sufficient quantities (e.g., Glover and Presland 1985; Pasqua and Bulbeck 1998; Suryatman et al. 2019, 2020; Hasanuddin et al. 2020). The hematite selected for flaking was fine grained, and compact and hard enough to produce flakes with sharp and durable margins. Hematite artefacts occurred in high numbers in spits 4-6, in the same context as the human remains. Furthermore, this material was also utilized to manufacture Maros points and retouched scrapers (Figure 6).

Based on these results, this study reveals that the cultural layer associated with the human burials is estimated to date to at least $6396 \mathrm{cal} \mathrm{BP}$, or the Middle Holocene period. The lack of ceramic 
fragments in spits 5 and 7 indicates the youngest age might be estimated to be greater than $3.5 \mathrm{kya}$, before the influence of Austronesian-speaking migrants reached southern Sulawesi (e.g. Simanjuntak 2015). Indications of Middle Holocene occupancy are further reinforced by the presence of Toalean artefacts, which are found throughout the region and thought to date to between 8 and 3.5 kya (Bulbeck et al. 2001; Suryatman et al. 2019, 2020; Hasanuddin et al. 2020).
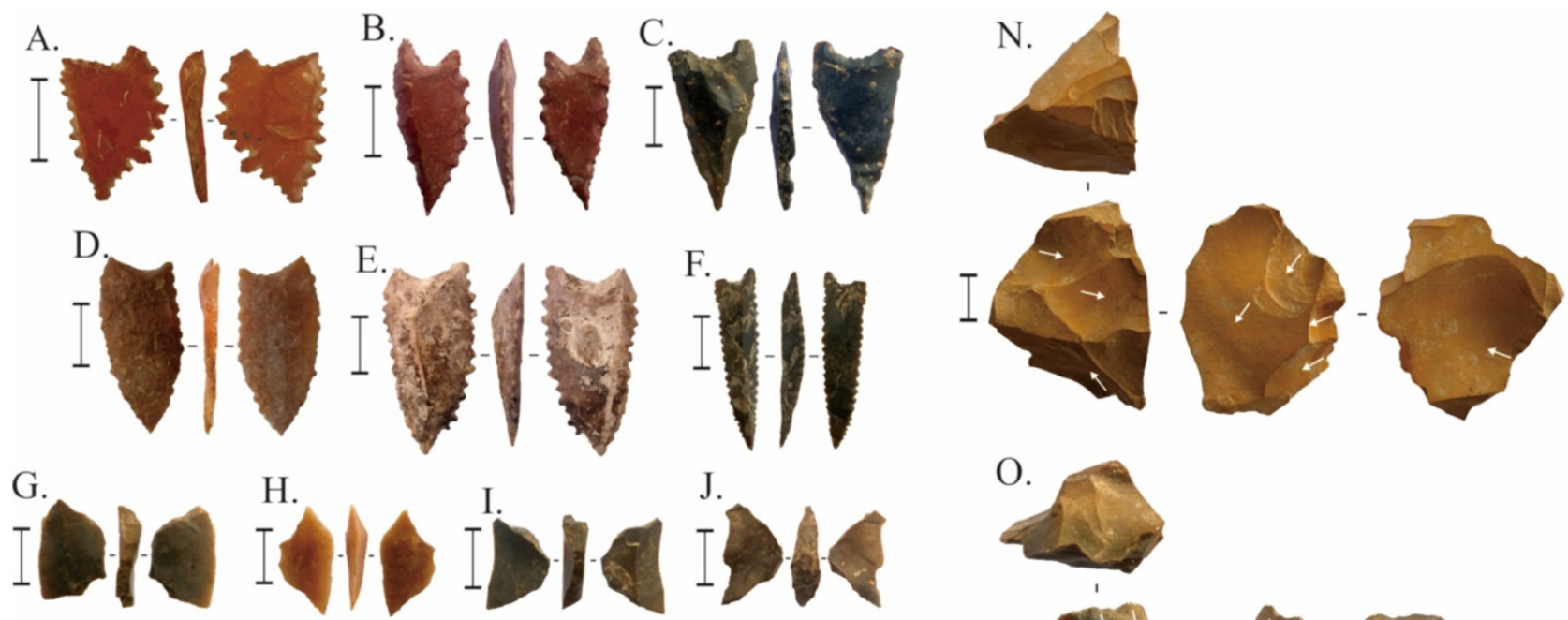

J.
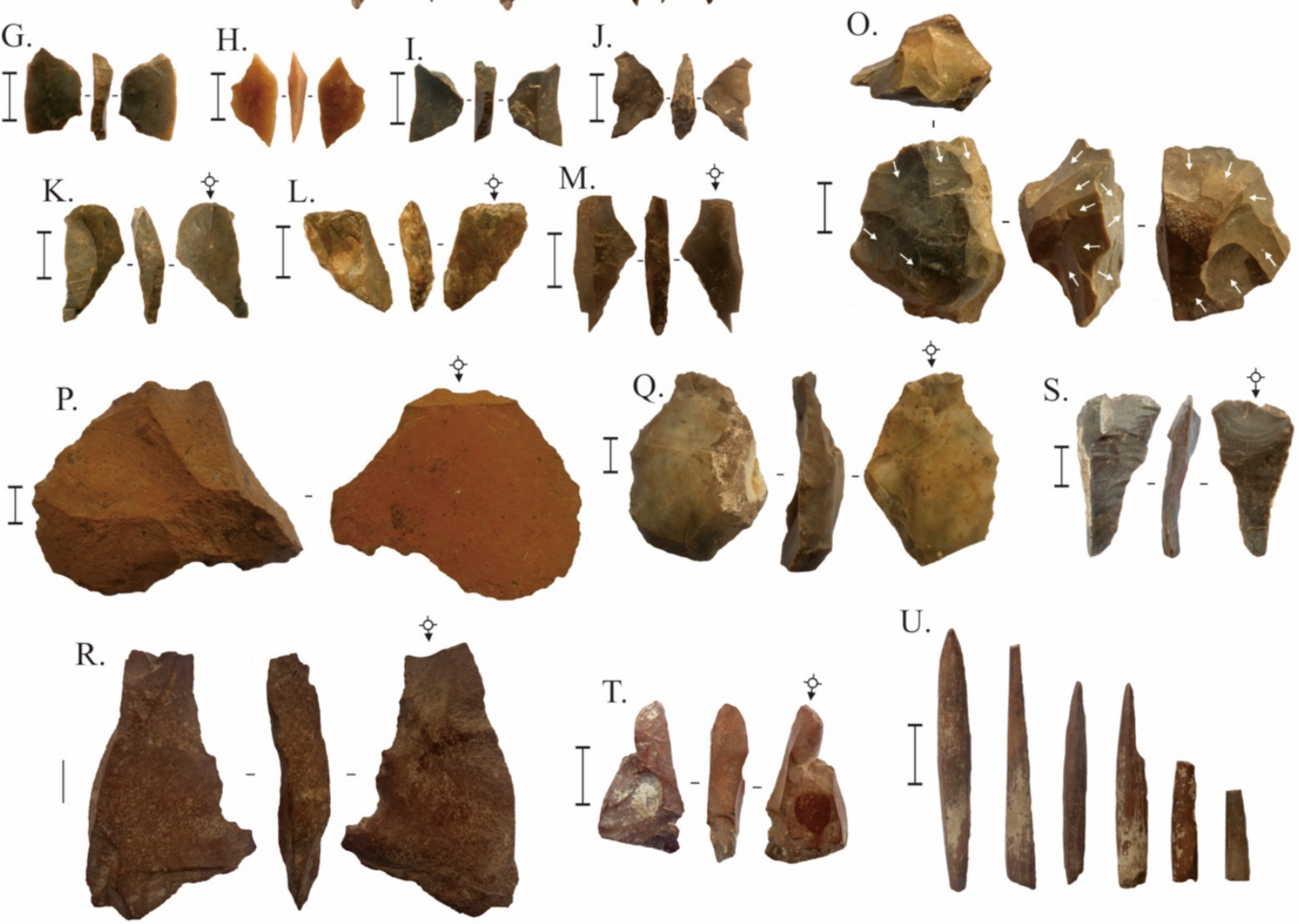

Fig. 6 Lithic artefacts and bone points from the Cappalombo 1 site. Lithic artefacts include Maros points (A. U1T2/5, B. TP2/5, C. TP2/1, D. TP2/4, E. TP2/5, and F. TP1/4), geometric microliths (G. TP2/2, H. TP2/2. TP2/2, I., J. TP2/3), asymmetric microliths (K. U1T2/2, L. U1T2/3, M. U1T2/1), cores (N. TP1/6, O. TP1/2), retouched scrapers (P. TP2/4, Q. TP1/6 and R. TP2/4) and debitage (S. TP 2/5, T. U1T2/4). White arrows on the cores indicate the direction of flake removals. Bone points were recovered from square U1T1, spit 5 (U). Flake artefacts are made of hematite (A, B, N, P, R and T) and chert (C, D, E, F, G, H, I, J, K, L O and Q). Scale bar: $1 \mathrm{~cm}$. 


\section{Methods}

All stone flakes and nodules of hematite (ochre) were inspected for incised lines. The stone artifacts were retrieved from excavations carried out in 2017 and 2018. Given the lack of stratigraphic layers, both excavations were conducted in $10 \mathrm{~cm}$ spits. The length, width, and thickness of each incised line on each artefact was measured using a Mitutoyo CD-6” series AX calliper. The incised patterns were analysed using 3-dimensional imagery, generated using a Nikon D7500 camera, with the incised patterns redrawn using Coreldraw 2018 software. The drawings of the artefacts are intended to make it easier to observe the stroke patterns found on all artefacts so as to help in the interpretation of the data. We also performed microscopic observations using a portable digital microscope (Dinolite AM4113T5X) under 40-200x magnification to assess pigment powders found adhering to fragments of the human bones.

\section{Results}

The analysis identified ten artefacts that showed clear incised lines on the surface: eight stone flakes and two otherwise unmodified stone 'plaquettes', i.e., naturally tabular pieces of stone. The raw material of all incised flakes and stone fragments was identified as hematite, as a sample produced a red streak during a streak-test. The flaked artefacts have been categorized as 'complete flakes' meaning that they retain all recognizable attributes including a platform and bulb of percussion on the ventral face and did not break during removal from the core (step termination) nor have suffered significant post-production damage (Figure 7 and Table 4). Two artefacts, however, show secondary flaking along one of the lateral margins (Figure 7B and 7H).

\begin{tabular}{|l|l|l|l|l|l|l|l|}
\hline Label & Classification & Square & Spit & $\begin{array}{l}\text { Length } \\
(\mathrm{mm})\end{array}$ & $\begin{array}{l}\text { With } \\
(\mathrm{mm})\end{array}$ & $\begin{array}{l}\text { Thickness } \\
(\mathrm{mm})\end{array}$ & $\begin{array}{l}\text { Weight } \\
\text { (gram) }\end{array}$ \\
\hline A & Complete flake & TP1 & 4 & 30.50 & 30.22 & 6.19 & 5.01 \\
\hline B & Retouched flake & TP2 & 3 & 33.00 & 31.38 & 5.15 & 6.24 \\
\hline C & Complete flake & U1T2 & 4 & 27.19 & 26.62 & 8.76 & 5.92 \\
\hline D & Complete flake & TP1 & 5 & 27.25 & 24.82 & 13.04 & 6.68 \\
\hline E & Complete flake & TP2 & 2 & 27.44 & 32.42 & 12.22 & 6.50 \\
\hline F & Complete flake & TP1 & 4 & 19.61 & 14.83 & 7.25 & 1.52 \\
\hline G & Complete flake & S1T1 & 6 & 47.27 & 13.23 & 2.99 & 2.05 \\
\hline H & Retouched flake & S1T1 & 6 & 36.63 & 39.15 & 9.21 & 18.10 \\
\hline
\end{tabular}

Table 4 Context, size, and weights of incised flakes from Cappalombo 1 excavation squares TP1, TP2, U1T2 and S1T1. Label category refers to artefact labels in Figure 7. 

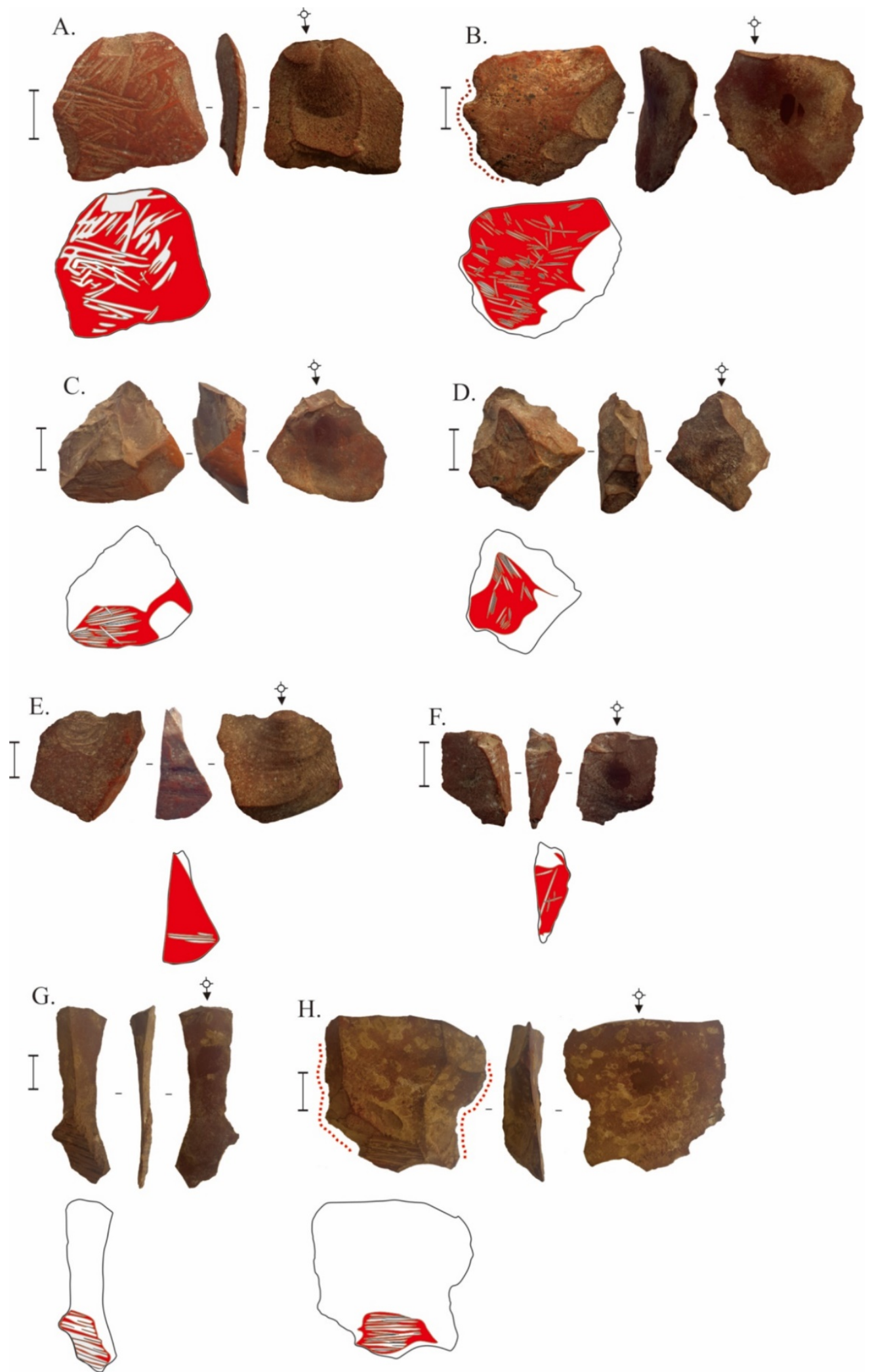

Fig. 7 Incised patterns identified on stone artefacts from Cappalombo 1. All incised artefacts are unmodified flakes, with the exception of (B) and (H), both of which have retouch along one or more lateral margins. Incised patterns occur only on the cortical surfaces of the artefacts, sketched in red. The artefact context information and measurements are found in Table 4 . Scale bar: $1 \mathrm{~cm}$. 
Most of the incised artefacts were found in spits 4, 5 and 6 at depths of between 50 and $80 \mathrm{~cm} \mathrm{BD.}$ However, two artefacts were recovered from spits 2 and 3, at a depth of 30 to $50 \mathrm{~cm} \mathrm{BD.} \mathrm{The} \mathrm{flakes}$ measurements range from 47 to $19 \mathrm{~mm}$ long, 32 and $13 \mathrm{~mm}$ wide, and 2 to $13 \mathrm{~mm}$ in thickness, while the weight ranges from 1 to 18 grams (Table 4 ).

Our analysis determined that the incisions were almost certainly produced by scraping the surface of the hematite with a sharp object, most likely the edge of another flake as these are abundant at the site and would be sufficiently sharp and strong. The incisions are defined and discrete, with a V-shaped cross-section, indicative of production through a short, firm cutting or scratching motion. The random, non-parallel orientation of the marks and inconsistency in their depths rules out grinding or rubbing (e.g., Mackay \& Welz 2008), and such marks do not occur as a direct outcome of flake production. In some instances, the incisions were so intense as to cover the entire cortical surface (Figures 7A, 7G and 8A).

All incised lines were made on the residual cortex of the flakes, and this cortex has a soft, chalky texture. Two of the flakes were intensely incised so that most of the dorsal cortex is covered in incisions. (Figure 7A and B). The other flakes only retain a small amount of cortex and therefore show fewer incisions (Figure 7C, D, E, F, G, and H). Some of the visible incisions on the cortex are truncated, suggesting that these marks were made before these flakes were struck from the core. Most incisions show a similar pattern of parallel, repeated, and irregular lines, however some dissect or run perpendicular to each other. The incised lines do not form any symmetrical shapes.

Incised flakes have previously been reported from the cultural layers at Leang Bulu Bettue (Brumm et al. 2017, 2020), dating to the Late Pleistocene. At this site, incisions have also been identified on the cortex of flakes and stone fragments, as is the case with the Cappalombo 1 artefacts. However, there are differences in the raw materials used; at Leang Bulu Bettue incised artefacts were made of chert - sometimes known as silicified limestone - while at Cappalombo 1 the incised artefacts are hematite. The incised artefacts from Leang Bulu Bettue come in a range of forms, including light markings not visible to the naked eye (Brumm et al. 2020) to elaborate and deep 'sun-motif' designs (Langley et al. 2020). However, the incision pattern seen on the Leang Bulu Bettue artefacts is not as clear as very little of the cortex is engraved.

Two flat stone fragments or 'plaquettes' showed incision lines on their flat surfaces. One fragment was incised on only one face (Figure 8A), while the second was incised on both faces (Figure 8B). The first fragment was found at TP 2 spit 5, with a maximum length of $88.04 \mathrm{~mm}$, a maximum width of $67.53 \mathrm{~mm}$ and a maximum thickness of $7.59 \mathrm{~mm}$ (Figure 8A). Meanwhile, the second fragment was recovered from TP 1, spit 3, and measures a maximum length of $58.06 \mathrm{~mm}$, a maximum width of $56.83 \mathrm{~mm}$ and a maximum thickness of $9.08 \mathrm{~mm}$. The first fragment was intensely incised, though the width of these incisions tends to be thin compared to those on the second fragment. The incisions on both these stone fragments are onto a soft surface, as is also the case on the incised flakes. The first plaquette may have been incised on only one face because the surface of the opposite is relatively hard. The pattern of incisions seen on the two stone plaquettes does not differ greatly from the patterns identified on the stone flakes, this being repeated parallel lines that sometimes dissect or run perpendicularly to each other. The incisions on these stone fragments are very different from those described at Leang Bulu Bettue (Brumm et al. 2017, 2020; Langley et al. 2020), as the patterns on the Leang Bulu Bettue artefacts are more structured than those seen at Cappalombo 1. The selection of raw material is also different, as the incised stone 
fragments from Leang Bulu Bettue are made of limestone and chert, including one piece of flowstone.

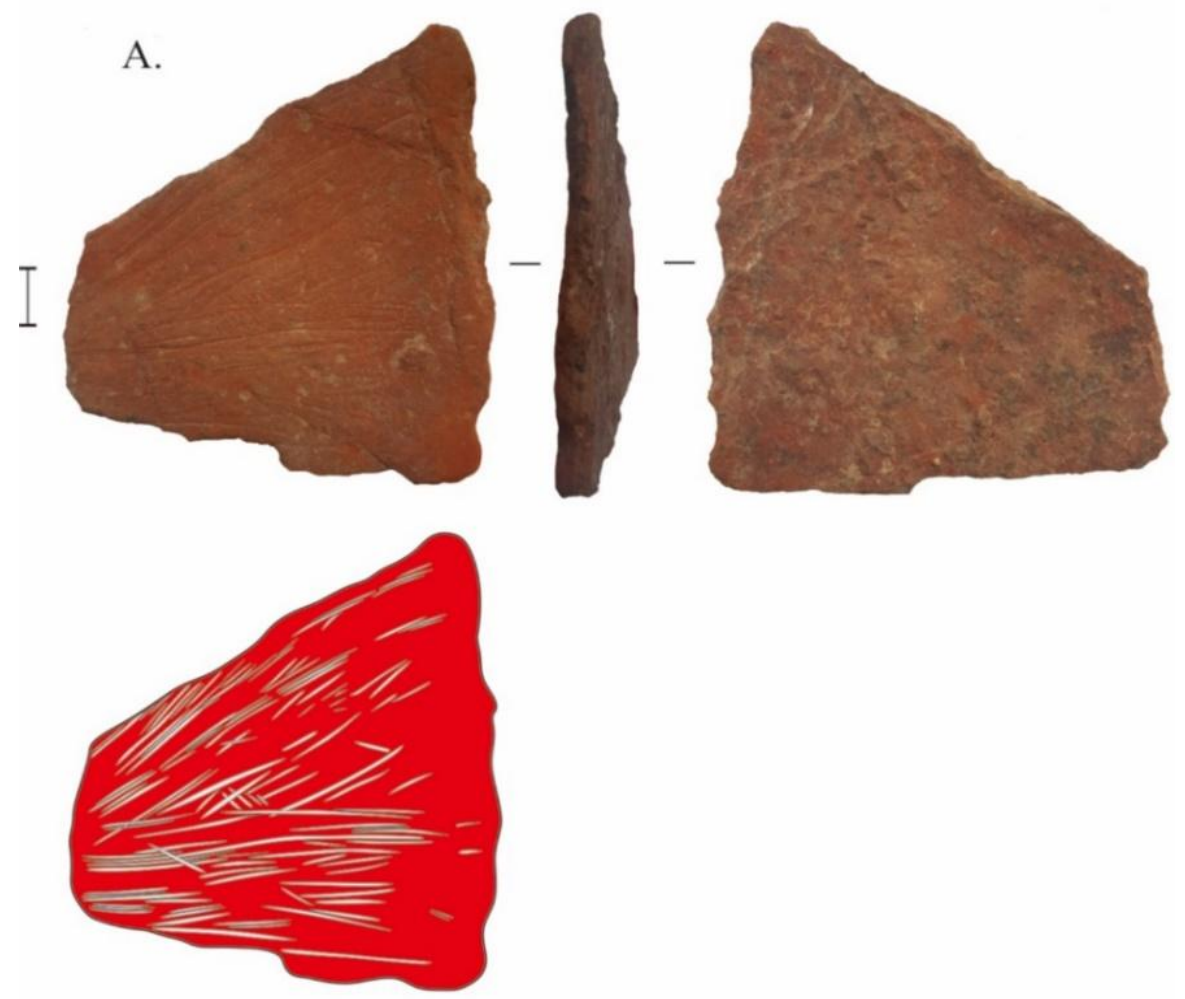

B.
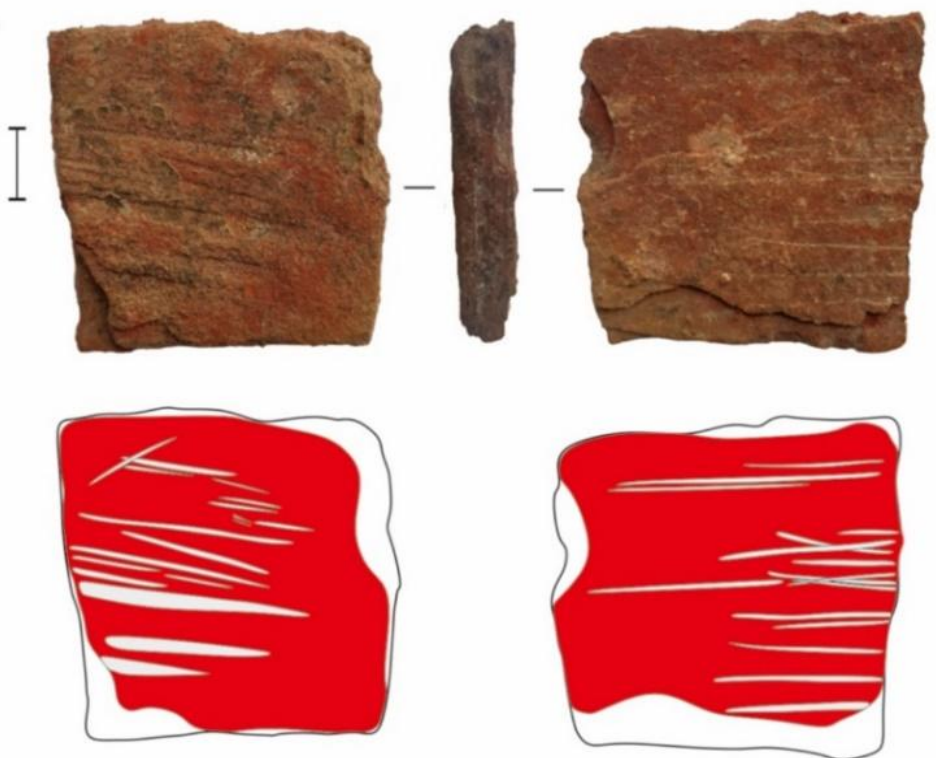

Fig. 8 Stone plaquettes recovered from Cappalombo 1 showing parallel incisions across a flat surface. One fragment was found in TP 2, spit 5, and is incised on one face (A) while the second was recovered from TP1, spit 3, and has incisions on both faces (B). Scale bar: $1 \mathrm{~cm}$.

In addition to the engraved hematite plaquettes and flakes, red deposits were observed on a number of skeletal elements, resembling ochre residues. Six cranial fragments from the CPL1 individual were identified as having red staining. Given the lack of discoloration to the rest of the skeletal assemblage this does not appear to be post-depositional staining from the surrounding substrate. 
This was further confirmed by digital magnification (47-196x), which showed the colouration to be a layer of pigment adhering to the surface of the bones (Figure 9). These bone fragments are undergoing further analysis, but initial results are strongly indicative of these being ochre residues.
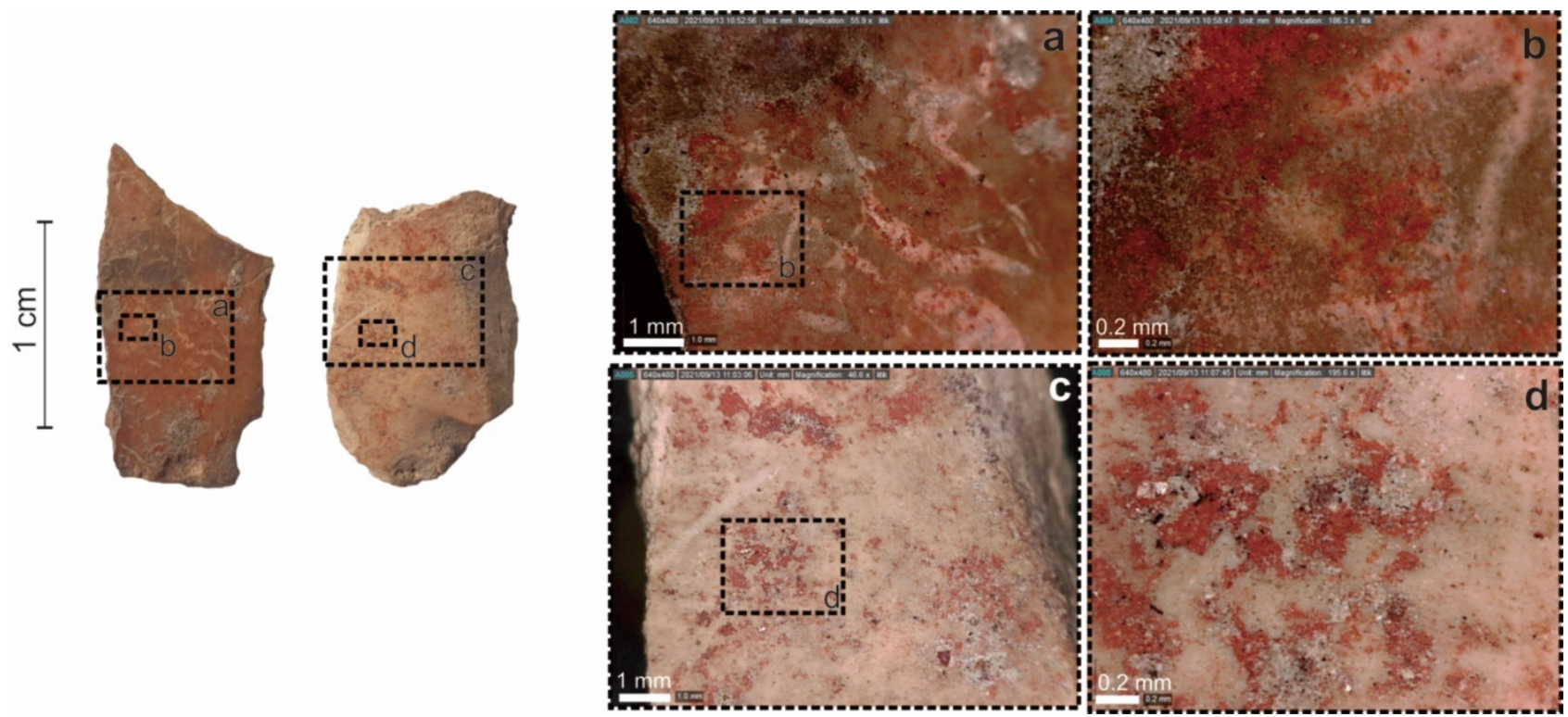

Fig. 9 A magnified view of two samples of cranial fragments of CPL1, showing the presence of red pigments attached to the bone surface.

\section{Discussion}

The discovery of ten incised stone artefacts at Cappalombo 1 adds to the limited data reported from Holocene occupation sites. These finds are made more remarkable by the fact they were recovered associated with human remains, which are rarely preserved in this region (Carlhoff et al. 2021). Radiocarbon dating suggests that the incised stone artefacts are associated with an age of at around $6396 \mathrm{cal}$ BP, or the Middle Holocene period. The presence of diagnostic Toalean artefacts further supports this age estimate, as the established production period for these artefacts sits between ca. 8-3.5 kya (e.g., Bulbeck et al. 2001; Suryatman 2017; Suryatman et al. 2017, 2019; Hasanuddin et al. 2020).

Eight hematite flakes had incised marks, and these are limited to cortical surfaces on the dorsal face. Two further hematite plaquettes have incised lines on the flat surfaces. All ten incised items were of the same raw material, namely hematite, and the incisions were made on particularly soft surfaces that left a red residue on contact. All artefacts show a similar pattern of repeated, apparently haphazard, parallel lines that sometimes dissect (Figures 6 and 7). Unlike examples found elsewhere in the world that have been interpreted as artistic or ritualistic markings (e.g., Mullan and Wilson 2004; O'Grady 2019), the incision patterns on the Cappalombo hematite pieces are neither figurative nor geometric. It, therefore, appears that no grounds can be made for ascribing symbolic meaning, although this can never be entirely ruled out. The incised marks on artefacts from this site are also very different to the geometric patterns of the clear rayed circle and apparent anoa (a small buffalo species) engraving reported in Langley et al. (2020) from Pleistocene deposits at Leang Bulu Bettue, though do perhaps more closely resemble some of the repetitive linear markings and crosshatching reported in Brumm et al. (2020) at the same site. 


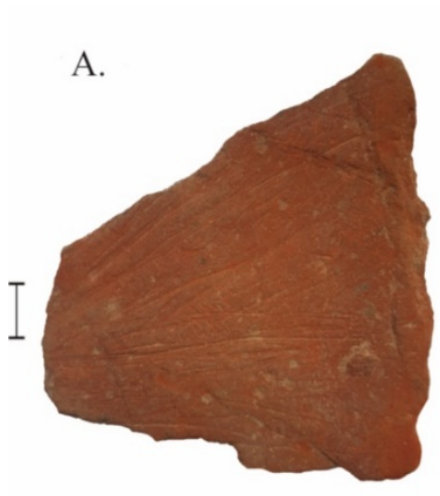

C.
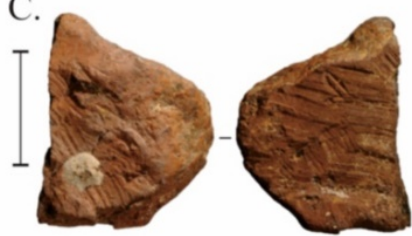

D.

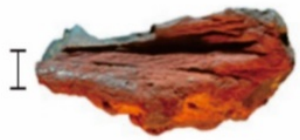

B.

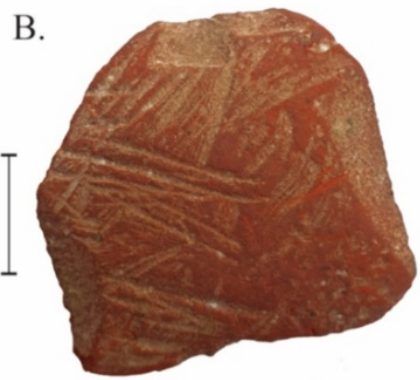

F.
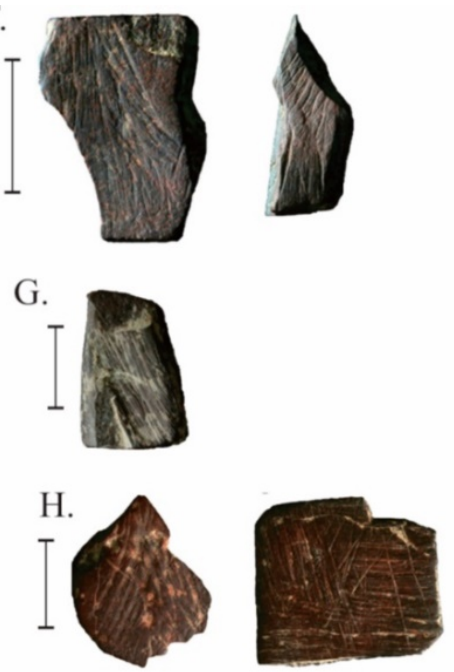

I.

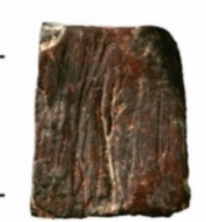

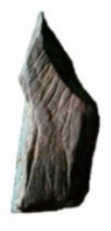

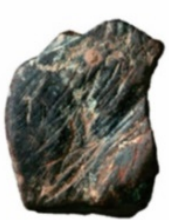

Fig. 10 Incised hematite artefacts from Cappalombo 1 and some examples of etched ochre from other sites, showing repeated unidirectional patterns with occasional divergent or intersecting lines. Stone plaquettes (A) and flakes (B) from Cappalombo 1. Incised ochre from the Late Pleistocene cultural layers of Leang Burung 2 (C) and Leang Bulu Bettue (E), South Sulawesi (Source: Brumm et al., 2018; 2017). Incised ochre from the Late Pleistocene sites of Jerimalai (F), Lene Hara (G), Matja Kuru 1 (H), and Matja Kuru 2 (I) in Timor Leste (Source: Langley and O’Connor, 2018; 2019). Scale bars: $1 \mathrm{~cm}$.

The patterns seen on all the Cappalombo 1 artefacts resemble marks found on ochre pieces at a number of Late Pleistocene sites (Figure 10). In Africa, parallel incised lines have been identified on ochre pieces at the Blombos, Sibudu, and Porc-Epic caves sites, and these are estimated to date to between 90-30 kya (Henshilwood et al. 2009; Hodgskiss 2013; Rosso et al. 2017). Incised ochre has also been reported at several other sites in ISEA, these examples date to between 42-10 kya. These were recovered from a number of sites including Asitau Kuru (Jerimalai), Lene Hara, and Matja Kuru 1 in Timor Leste (Langley and O'Connor 2019; Shipton et al. 2019) and Leang Bulu Bettue and Leang Burung 2 in South Sulawesi (Glover 1981: Plate 8; Brumm et al. 2017, 2018), as well as chert flakes with ochre residues at Leang Bulu Bettue which may have been utilised for processing ochre (Brumm et al. 2017). Experimental studies have shown that the linear patterns occur on ochre when the stone is scraped to produce powdered pigments. One method of doing this is to repeatedly scratch the surface of the ochre with a sharp object such as a flake, resulting in a series of linear incisions like those of the Cappalombo artefacts (Hodgskiss 2010; Rifkin 2012). Based on these comparisons, our analysis indicates that the incisions on the stone artefacts from Cappalombo 1 may therefore be the by-product of the production of pigmented powders. The importance of red pigment at the site is also supported by the abundance of ochre (hematite) nodules recovered from the excavations, as these ochre pieces may have served a similar purpose.

The next question that arises is what the pigment powder at Cappalombo 1 was used for. The discovery of ochre in the context of Late Pleistocene sites in South Sulawesi is often attributed to the production of art (Brumm et al. 2017, 2020). Moreover, minimum ages from dated rock art in 
the Maros and Pangkep regions only shows an age range between 46 and 18 kya, and no cave art has yet been dated to the Toalean period (Aubert et al. 2014, 2019; Brumm et al. 2021). In contrast with the Late Pleistocene layers at Leang Bulu Bettue and Leang Burung 2, recent results from Toalean layers showed no indication of intensive ochre use (Suryatman et al. 2019, 2020; Hasanuddin et al. 2020). Thus, linking the use of powdered pigment at Cappalombo 1 to painting or the creation of rock art is still inconclusive.

Red ochre has been interpreted as being culturally significant throughout the ancient world. Apart from being used as a paint colour, coloured pigment was often applied to parts of the body in the context of symbolic rituals, such as burial practices and other activities (Lemke et al. 2015; Langley and O'Connor 2019; MacDonald et al. 2020). On the other hand, ochre is also thought to perform practical functions, such as use as an antiseptic, sunscreen, and to clean away pests or parasites that irritate the skin (Velo 1984; Rifkin 2015; Rifkin et al. 2015).

In the Southeast Asian context, the colour red is believed to have a prehistoric meaning symbolising courage, power, and strength (Langley and O'Connor 2019). It is quite common for ochre to be found in late Pleistocene to Holocene sites (see Langley and O'Connor 2018, 2019). The use of ochre in pre-Neolithic burials has also been widely documented in the Southeast Asia region (Simanjuntak and Asikin 2004; Anderson 2005; Barker et al. 2005; O'Connor et al. 2017; Bellwood 2007; Lloyd-Smith 2012; Nguyen 2015), including recently reported instances at Makpan, Alor Island, Indonesia (Samper Carro et al. 2021). Thus, we suggest that it is likely that the ochre from Cappalombo 1 may have been part of a burial tradition that was prevalent in Southeast Asian prehistorical cultures. The results of microscopic observations using high power magnification from two cranial fragments of CPL1 showed the presence of red pigment powders that were still attached to the bone surface (Figure 9). On this basis we suggest that the red powdered pigment that would have been produced from these scratches was likely applied, perhaps as a paint or a raw powder, to the bodies of the corpses or to the performers themselves as part of a burial ritual that took place at the site.

\section{Conclusion}

The incised stone artefacts from Cappalombo 1 indicate that symbolic behaviours continued into the Middle Holocene with the Toalean culture. However, this period lacks evidence for the expression of symbolic behaviour in the form of rock art or figurative portable engravings, as had been the case in the Late Pleistocene. It is strongly suspected that the incised marks identified on Toalean-age hematite flakes and plaquettes at Cappalombo were produced through repeatedly scratching the surface in order to produce red powdered pigment. The presence of these findings in the context of a burial suggests that the powder was likely used as part of symbolic ritual practices applied to the corpses or perhaps the powder played a part in the performance of the ceremony itself.

The context of the finds at Cappalombo 1 adds to our understanding of the use of red pigments in pre-Neolithic burial traditions throughout Southeast Asia, and especially in South Sulawesi where our understanding of such activities is still somewhat limited. The findings also confirm that hematite was not always associated with rock art, but likely played a wider role in prehistoric cultures and cave use. Over a thousand flakes made of hard hematite were analysed from Cappalombo 1, eight of which have incised lines on the cortical surfaces, suggesting that this material was adapted for both pigment production and flaked tool construction. The human 
skeletons at this site still hold important information that is yet to be investigated, and research must continue on these finds to enrich our understanding of pre-Neolithic burial practices in South Sulawesi and Southeast Asia in general.

\section{Acknowledgement}

Thank you to the head of Pusat Penelitian Arkeologi Nasional who provided funding to the research team so that this research could be implemented properly. We also extend our gratitude and appreciation to Dr. M. Irfan Mahmud, M.Si, as Head of Balai Arkeologi Provinsi Sulawesi Selatan, who provided support during the research conducted in Bontocani region, Bone. Thanks also to friends and students from the Department of Archaeology, Hasanuddin University, who were actively involved in data collection, namely: Prayoga, Sirajuddin "Bambang", Marwan, Nurhelfia M., Wilda Amin, Siska, Salmiah, Yulastri, Tantra, Mega, Enrico and Hafdal. Thanks also to Delta bayu Murti from Airlangga University, who is currently conducting in-depth research on the human skeleton at the Cappalombo 1 Site and providing us with information about pigment powder attached to the skeleton. We also thank our three anonymous reviewers for their feedback and assistance is improving this paper.

\section{References}

Anderson, DD (2005) The use of caves in peninsular Thailand in the Late Pleistocene and Early and Middle Holocene. Asian Perspectives 44(1): 137-153.

Aubert, M, Brumm, A, Ramli, M, Sutikna, T, Saptomo, EW, Hakim, B, Morwood, MJ, van den Bergh, Kinsley, GL, and Dosseto, A (2014) Pleistocene cave art from Sulawesi, Indonesia. Nature 514: 223-27.

Aubert, M, Lebe, R, Oktaviana, AA, Tang, M, Burhan, B, Hamrullah, Jusdi, A, Abdullah, Hakim, B, Zhao, J-X, Geria, IM, Sulistyarto, PH, Sardi, RM, and Brumm, A (2019) Earliest hunting scene in prehistoric art. Nature 576: 1-4.

Aubert, M, Setiawan, P, Oktaviana, AA, Brumm, A, Sulistyarto, PH, Saptomo, EW, Istiawan, B, Ma'rifat, TA, Wahyuono, VN, Atmoko, FT, Zhao, J-X, Huntley, J, Taçon, PSC, Howard, DL, and Brand, HEA (2018) Palaeolithic cave art in Borneo. Nature 564: 254-257.

Barker, G, Reynolds, T, and Gilbertson, DD (2005) The human use of caves in peninsular and Island Southeast Asia: Research themes. Asian Perspectives 44(1): 1-15.

Bellwood, P (2007) Prehistory of the Indo-Malaysian Archipelago. Canberra: ANU E Press.

Bronk Ramsey, C (2021) OxCal v4.4.4. Available at: https://c14.arch.ox.ac.uk/oxcal.html [accessed 20 September 2021].

Brumm, A, Hakim, B, Ramli, M, Aubert, M, van den Bergh, G, Li, B, Burhan, B, Saiful, AM, Siagian, L, Sardi, RM, Jusdi, A, Abdullah, Mubarak, AP, Moore, MW, Roberts, RG, Zhao, J-X, McGahan, D, Jones, BG, Perston, Y, Szabó, K, Mahmud, MI. Westaway, K., Jatmiko, Saptomo, WE, van der Kaars, S, Grün, R, Wood, R, Dodson, J, and Morwood, MJ (2018) A reassessment of the early archaeological record at Leang Burung 2, a Late Pleistocene rock-shelter site on the Indonesian island of Sulawesi.” PLoS ONE 13(4): 1-43.

Brumm, A, Langley, MC, Hakim, B, Perston, Y, Suryatman, Oktaviana, AA, Burhan, B, and Moore, MW (2020) Scratching the surface: Engraved cortex as portable art in the Pleistocene Sulawesi. Journal of Archaeological Method and Theory 27(3): 1-29.

Brumm, A, Langley, MC, Moore, MW, Hakim, B, Ramli, M, Sumantri, I, Burhan, B, Saiful, AM, Siagian, L, Suryatman, Sardi, RM, Jusdi, A, Abdullah, Mubarak, AP, Hasliana, Hasrianti, Oktaviana, AA, Adhityatama, S, van den Bergh, GD, Aubert, M, Zhao, J-X, Huntley, J, Li, 
B, Roberts, RG, Saptomo, EW, Perston, Y, and Grün, R (2017) Early human symbolic behavior in the Late Pleistocene of Wallacea. PNAS 114(16): 4105-4110.

Brumm, A, Oktaviana, AA, Burhan, B, Hakim, B, Lebe, R, Zhao, J-X, Sulistyarto, PH, Ririmasse, M, Adhityatama, S, Sumantri, I, and Aubert, M (2021) Oldest cave art found in Sulawesi. Science Advances 7(3): eabd4648.

Bulbeck, D, Pasqua, M, and Di Lello, A (2001) Culture history of the Toalean of South Sulawesi, Indonesia. Asian Perspectives 39(1): 71-108.

Carlhoff, S, Duli, A, Nägele, K, Nur, M, Skov, L, Sumantri, I, Oktaviana, AA, Hakim, B, Burhan, B, Syahdar, FA, McGahan, DP, Bulbeck, D, Perston, Y, Newman, K, Saiful, AM, Ririmasse, M, Chia, S, Hasanuddin, Pulubuhu, DAT, Suryatman, Supriadi, Jeong, C, Peter, BM, Prüfer, K, Powell, A, Krause, J, Posth, C, and Brumm, A (2021) Genome of a middle Holocene hunter-gatherer from Wallacea. Nature 596: 543-547.

Clarkson, C, Petraglia, M, Harris, C, Shipton, C, and Norman, K (2018) The South Asian Microlithic: Homo Sapiens Dispersal or Adaptive Response? In: E Robinson and F Sellet (eds) Lithic Technological Organization and Paleooenviromental Change. Studies in Human Ecology and Adaptation, vol. 9. Cambridge: Springer.

d'Errico, F, and Henshilwood, CS (2011) The Origin of Symbolically Mediated Behaviour: From Antagonistic Scenarios to a Unified Research Strategy. In: CS Henshilwood and F d'Errico (eds) Homo Symbolicus: The dawn of Language Imagination and Spirituality. Amsterdam/Philadelphia: John Benjamins B. V., 49-73.

Dutkiewicz, E, Russo, G, Lee, S, and Bentz, C (2020) SignBase, a collection of geometric signs on mobile objects in the Paleolithic. Scientific Data 7(364): 1-14.

Fakhri (2017) Laporan Penelitian Arkeologi: Penelitian Prasejarah Kawasan Situs Bontocani [Archaeological Research Report: Prehistoric Research of the Bontocani Site Region] [Unpublished work]. Makassar: Balai Arkeologi Sulawesi Selatan.

Fakhri (2018). Arkeofauna kawasan karst Bontocani Kabupaten Bone, Sulawesi Selatan [The Archaeofauna of Bontocani Karst Area, South Sulawesi]. Walennae, 16(1): 21-38.

Fakhri, Hakim, B, Suryatman, Sardi, R and Hasliana (2018) Eksplorasi Gua-Gua Prasejarah Kawasan Kars Bontocani: Fase Hunian Dan Lapisan Budaya Dari Pleistosen Akhir Hingga Holosen Di Dataran Tinggi Sulawesi Selatan [Exploration of Prehistoric Caves in the Bontocani Karst Region: Occupation Phases and Cultural Layers from Late Pleistocene to Holocene in the Highlands of South Sulawesi] [Unpublished work]. Makassar: Balai Arkeologi Sulawesi Selatan.

Glover, IC 1981. Leang Burung 2: An upper palaeolithic rock shelter in south Sulawesi, Indonesia. Modern Quaternary Research in Southeast Asia 6: 1-38.

Glover, IC and Presland, G (1985) Microliths in Indonesian flaked stone industry. In: VN Misra and P Bellwood (eds.) Recent Advances in Indo-Pacific Prehistory. New Delhi and Leiden: E.J. Brill, 185-195.

Hasanuddin, Bernadeta, Saiful, AM, Yondri, L, Sumantri, I, Nur, M, Supriadi, Lebe, R, Isbahuddin, Al Ansyary, K, and Sirajuddin, K (2020) Interaction between the Toalean and Austronesian cultures in the Mallawa Area, Maros District, South Sulawesi. Journal of Indo-Pacific Archaeology 44: 329-49.

Heaton, TJ, Köhler, P, Butzin, M, Bard, E, Reimer, RW, Austin, WEN, Bronk Ramsey, C, Grootes, PM, Hughen, KA, Kromer, B, Reimer, PJ, Jess, A, Burke, A, Cook, MS, Olsen, J, and 
Skinner, LC (2020) Marine20 - The marine radiocarbon age calibration curve (0-55,000 cal BP). Radiocarbon 62 (4): 779-820.

Henshilwood, CS, and d'Errico, F (2011) Middle Stone Age Engravings and Their Significance to the Debate on the Emergence of Symbolic Material Culture. In CS Henshilwood and F d'Errico (eds). Homo Symbolicus: The Dawn of Language Imagination and Spirituality. Amsterdam/Philadelphia: John Benjamins B.V., 97-110.

Henshilwood, CS, d'Errico, F, van Niekerk, KL, Dayet, L, Queffelec, A, and Pollarolo, L (2018) An abstract drawing from the 73,000-year-old levels at Blombos Cave, South Africa. Nature 562: 115-118.

Henshilwood, CS, d'Errico, F, and Watts, I (2009) Engraved ochres from the Middle Stone Age levels at Blombos Cave, South Africa. Journal of Human Evolution 57: 27-47.

Henshilwood, CS, d'Errico, F, Yates, R, Jacobs, Z, Tribolo, C, Duller, GAT, Norbert Mercier, Sealy, JC, Valladas, H, Watts, I, and Wintle, AG (2002) Emergence of modern human behavior: Middle Stone Age engravings from South Africa. Science 295(5558): 1278-1280.

Hiscock, P, Clarkson, C, and Mackay, A (2011) Big debates over little tools: Ongoing disputes over microliths on three continents. World Archaeology 43(4): 37-41.

Hodgskiss, T (2010) Identifying grinding, scoring and rubbing use-wear on experimental ochre pieces. Journal of Archaeological Science 37: 3344-58.

Hodgskiss, T (2013) Ochre use in the Middle Stone Age at Sibudu, South Africa: Grinding, rubbing, scoring and engraving. Journal of African Archaeology, 11(1): 75-95.

Huntley, J (2021) Australian Indigenous Ochres: Use, Sourcing, and Exchange. In: IJ McNiven and B David (eds). The Oxford Handbook of the Archaeology of Indigenous Australia and New Guinea. Published online by Oxford University Press.

Langley, MC, Hakim, B, Oktaviana, AA, Burhan, B, Sumantri, I, Sulistyarto, PH, Lebe, R, McGahan, D, and Brumm, A (2020) Portable art from Pleistocene Sulawesi. Nature Human Behaviour 4: 597-602.

Langley, MC, and O’Connor, S (2018) Exploring Red Ochre Use in Timor-Leste and Surrounds: Headhunting, Burials, and Beads. In: MC Langley, M Litster, D Wright and SK May (eds). The Archaeology of Portable Art: Southeast Asian, Pacific, and Australian Perspectives. Routledge. 25-36.

Langley, MC and O’Connor, S (2019) 40,000 Years of ochre utilization in Timor-Leste: Powders, prehensile traces, and body painting. PaleoAnthropology, 2019: 82-104.

Lemke, AK, Wernecke, DC, and Collins, MB (2015) Early art in North America: Clovis and later Paleoindian incised artifacts from the Gault Site, Texas (41BL232). American Antiquity 80 (1): 113-133.

Lloyd-Smith, L (2012) Early Holocene burial practice at Niah Cave, Sarawak. Journal of IndoPacific Archaeology 32: 54-69.

MacDonald, BL, Chatters, JC, Reinhardt, EG, Devos, F, Meacham, S, Rissolo, D, Rock, B, Le Maillot, C, Stalla, D, Marino, MD, Lo, E, and Erreguerena, PL (2020) Paleoindian ochre mines in the submerged caves of the Yucatan Peninsula, Quintana Roo, Mexico. Science Advances 6(27): eaba1219.

Mackay, A, and Welz, A (2008) Engraved ochre from a Middle Stone Age context at Klein Kliphuis in the Western Cape of South Africa. Journal of Archaeological Science 35: 15211532. 
Malafouris, L (2021) Mark making and human becoming. Journal of Archaeological Method and Theory 28: 95-119.

Mellars, P, Gori, KC, Carr, M, Soares, PA and Richards, MB (2013) Genetic and archaeological perspectives on the initial modern human colonization of Southern Asia. Proceedings of the National Academy of Science, 110(26): 10699-10704.

Mullan, GJ, and Wilson, LJ (2004) A possible Mesolithic engraving in Aveline’s Hole, Burrington Combe, North Somerset. Proceedings of the University of Bristol Spelcoloical Society 23(2): 75-85.

Nguyen, V (2015) First Archaeological Evidence of Symbolic Activities from the Pleistocene of Vietnam. In: Y Kaifu, M Izuha, T Goebel, H Sato and A Ono (eds.) Emergence and Diversity of Modern Human Behavior in Paleolithic Asia. College Station: Texas A\&M University Press, 133-139.

O'Connor, S, Aplin, K, Pierre, ES and Feng, Y-X (2010) Faces of the ancestors revealed: discovery and dating of a Pleistocene-age petroglyph in Lene Hara Cave, East Timor. Antiquity, 84: 649-665.

O’Connor, S, Mahirta, Carro, SCS, Hawkins, S, Kealy, S, Louys, J and Wood, R (2017) Fishing in life and death: Pleistocene fish-hooks from a burial context on Alor Island, Indonesia. Antiquity, 91(360): 1451-1468.

O’Connor, S, Oliveira, NV, Standish, CD, García-Diez, M, Kealy, S and Shipton, C (2020) Faces in the Stone: Further Finds of Anthropomorphic Engravings Suggest a Discrete Artistic Tradition Flourished in Timor-Leste in the Terminal Pleistocene. Cambridge Archaeological Journal, 31(1): 129-142.

O’Grady, J (2019) The evolution of symbolic inscription in prehistory. The Post Hole 52: 62-78.

Pasqua, M, and Bulbeck, D (1998) A Technological Interpretation of the Toalean, South Sulawesi. In: G-J Bartstra (ed.) Bird's Head Approaches: Irian Jaya Studies-A Programme for Interdisciplinary Research. Rotterdam, Netherlands; Brookfield, VT: Balkema, 221-231.

Perston, YL, Sumantri, I, Hakim, B, Oktaviana, AA and Brumm, A (2020) Excavation Report For Leang Rakkoe: A New Toalean Site With Engraved Art In The Bomboro Valley, Maros Regency, South Sulawesi [Laporan Ekskavasi Terhadap Situs Rakkoe: Situs Toala yang Baru dengan Seni Pahat di Lembah Bomboro, Kabupaten Maros, Sulawesi Selatan]. WallenaE: Jurnal Arkeologi Sulawesi Selatan \& Tenggara, 18(1): 51-64.

Perston, YL, Moore, M, Suryatman, Langley, M, Hakim, B, Oktaviana, AA and Brumm, A (2021) A standardised classification scheme for the Mid-Holocene Toalean artefacts of South Sulawesi, Indonesia. PLoS One, 16(5): e0251138.

Petraglia, M, Clarkson, C, Boivin, N, Haslam, M, Korisettar, R, Chaubey, G, Metspalu, P, Roberts, RG and Arnold, LJ (2009) Population Increase and Environmental Deterioration Correspond with Microlith Innovations in South Asia ca. 35,000 Years Ago. Proceedings of the National Academy of Science, 106(30): 12261-12266.

Rifkin, RF (2012) Processing ochre in the Middle Stone Age: Testing the inference of Prehistoric behaviour from actualistically derived experimental data. Journal of Anthropological Archaeology, 31(2): 174-195.

Rifkin, RF (2015) Ethnographic and experimental perspectives on the efficacy of ochre as a mosquito repellent. South African Archaeological Bulletin, 70(201): 64-75. 
Rifkin, RF, Dayet, L, Queffelec, A, Summers, B, Lombard, M, and d'Errico, F (2015) Evaluating the photoprotective effects of ochre on human skin by In Vivo SPF assessment: Implications for human evolution, adaptation and dispersal. PLOS ONE 10(9): e0136090.

Rosso, DE, d'Errico, F, and Queffelec, A (2017) Pattern of change and continuity in ochre use during the Late Middle Stone Age of the Horn of Africa: The Porc-Epic cave record. PLoS ONE 12(5): e0177298.

Ruiz-Redondo, A, Garate, D, González-Morales, MR, Janković, I, Jaubert, J, Karavanić, I, Komšo, D, Kuhn, SL, Mihailović, D, Moro Abadía, O, Vander Linden, M, and Vukosavljević, N (2020) Beyond the bounds of Western Europe: Paleolithic art in the Balkan Peninsula. Journal of World Prehistory 33: 425-455.

Samper Carro, SC, Stewart, TJ, Mahirta, Wood, R, and O’Connor, S (2021) Burial practices in the early Mid-Holocene of the Wallacean Islands: A sub-adult burial from Gua Makpan, Alor Island, Indonesia. Quaternary International 603: 125-138.

Shipton, C, O’Connor, S, Jankowski, N, O’connor-Veth, J, Maloney, T, Kealy, S and Boulanger, C (2019) A new 44,000-year sequence from Asitau Kuru (Jerimalai), Timor-Leste, indicates long-term continuity in human behaviour. Archaeological and Anthropological Sciences, 11: 5717-5741.

Simanjuntak, T (2015) Progres penelitian Austronesia di Nusantara [Progress of Austronesian Studies in the Indonesian Archipelago]. Amerta 33(1): 25-44.

Simanjuntak, T, and Asikin, IN (2004) Early Holocene human settlement in Eastern Java. IndoPacific Prehistory Association Bulletin 2(24): 13-19.

Suryatman (2017) Artefak litik di kawasan Prasejarah Batu Ejayya: Teknologi peralatan Toalian di pesisir selatan Sulawesi Selatan [The Lithic Artefact at Batu Ejayya Prehitoric Region: The Technology of Toalian Tools in Southern Coast of Sulawesi]. Walennae 15(1): 1-18.

Suryatman, Fakhri, Sardi, R and Hakim, B (2020) Perkembangan teknologi artefak serpih batu pada paruh Awal Holosen di Leang Batti, Sulawesi Selatan [Development Of Stone Flake Artifact Technology In The Early Half Of Holocene At Leang Batti, South Sulawesi]. Berkala Arkeologi, 40(2): 195-218.

Suryatman, Hakim, B, and Harris, A (2017) Industri alat mikrolit di situs Balang Metti: Teknologi Toalean akhir dan kontak budaya di dataran tinggi Sulawesi Selatan [The Microlith Tool Industry at Balang Metti Site: Late Toalean Technology and Cultural Contact in the Highlands of South Sulawesi]. Amerta 35(2): 93-107.

Suryatman, Hakim, B, Mahmud, MI, Fakhri, Burhan, B, Oktaviana, AA, Saiful, AM, and Syahdar, FA (2019) Artefak batu Preneolitik situs Leang Jarie: Bukti teknologi Maros Point tertua di kawasan budaya Toalean, Sulawesi Selatan [The Pre-Neolithic Stone Artefact of Leang Jarie Site: The Oldest Evidence of Maros Point Technology in the Toalean Culture Region, South Sulawesi]. Amerta 37(1): 1-17.

Velo, J (1984) Ochre as medicine: A suggestion for the interpretation of the archaeological record. Current Anthropology 25(5): 674.

Yaroshevich, A, Bar-Yosef, O, Boaretto, E, Caracuta, V, Greenbaum, N, Porat, N, and Roskin, J. (2016) A unique assemblage of engraved plaquettes from Ein Qashish South, Jezreel Valley, Israel: Figurative and non-figurative symbols of Late Pleistocene hunters-gatherers in the Levant. PLoS ONE 11(8): e0160687. 